\title{
LOCATION CHOICE AND EMPLOYMENT DECISIONS: A COMPARISON OF GERMAN AND SWEDISH MULTINATIONALS
}

\author{
SASCHA O. BECKER \\ KAROLINA EKHOLM \\ ROBERT JAECKLE \\ MARC-ANDREAS MUENDLER
}

CESIFO WORKING PAPER NO. 1374

CATEGORY 4: LABOUR MARKETS

JANUARY 2005

\footnotetext{
An electronic version of the paper may be downloaded

- from the SSRN website:

www.SSRN.com

- from the CESifo website: www.CESifo.de
} 


\title{
LOCATION CHOICE AND EMPLOYMENT DECISIONS: A COMPARISON OF GERMAN AND SWEDISH MULTINATIONALS
}

\begin{abstract}
Using data for German and Swedish multinational enterprises (MNEs), this paper assesses international employment patterns. It analyzes determinants of location choice and the degree of substitutability of labor across locations. Countries with highly skilled labor forces attract German MNEs, but we find no such evidence for Swedish MNEs. This is consistent with the hypothesis that German MNEs locate production stages intensive in high-skilled labor abroad. In MNEs from either country, affiliate employment tends to substitute for employment at the parent firm. On the margin, substitutability is the strongest with respect to affiliate employment in Western Europe. A one percent larger wage gap between Germany and locations in Central and Eastern Europe $(C E E)$ is estimated to be associated with 900 fewer jobs in German parents and 5,000 more jobs in affiliates located in $C E E$. A one percent larger wage gap between Sweden and $C E E$ is estimated to be associated with 140 fewer jobs in Swedish parents and 260 more jobs in affiliates located in $C E E$.
\end{abstract}

JEL Code: F21, F23, J21, J23.

Keywords: multinational enterprises, location choice, multinomial choice, labor demand, translog cost function.

Sascha O. Becker

Center for Economic Studies and

Ifo Institute for Economic Research at the

University of Munich

Munich, Germany

sbecker@lmu.de

Robert Jaeckle

Ifo Institute for Economic Research

at the University of Munich

Munich, Germany

jaeckle@ifo.de
Karolina Ekholm

Stockholm School of Economics

P.O. Box 6501

11383 Stockholm

Sweden

Karolina.ekholm@hhs.se

Marc-Andreas Muendler

University of California, San Diego

92093-0508 La Jolla, CA

USA

muendler@ucsd.edu

We thank seminar and conference participants in Kiel, Leicester, Munich, Nottingham, Oslo and Stockholm, and Bernd Fitzenberger and Nannan Lundin in particular, for useful comments and discussions. We thank Heinz Herrmann, Alexander Lipponer and Fred Ramb for access to and ongoing support with the BuBa DIREK and USTAN data, and Ulf Jakobsson, Jörgen Nilsson and Christina Håkansson at IUI Stockholm for access and ongoing support with the IUI database on Swedish MNEs. Karin Herbst at BuBa kindly shared her stringmatching routine, Thomas Wenger patiently launched and oversaw string-matches in various iterations. Regis Barnichon, Chao Feng, and Daniel Klein provided excellent research assistance. We gratefully acknowledge financial support from the VolkswagenStiftung under its grant initiative Global Structures and Their Governance. Ekholm gratefully acknowledges financial support from the Swedish Research Foundation. 


\section{Introduction}

The expansion of domestic firms' operations abroad and the outsourcing of production stages to low-income countries in particular raise concerns about labor market consequences in high-income countries. Theory suggests that the foreign expansion of multinational enterprises (MNEs) may lead to a downward pressure on real wages for relatively scarce types of labor in the home country. However, besides cost reductions, an important motive for outward foreign direct investment (FDI) is market expansion. In fact, a major part of MNEs' foreign operations is concentrated in high- rather than low-income countries. In 2000, 63 percent of the foreign labor force of German MNEs worked in industrialized countries. Similarly, in 2002, 77 percent of the foreign labor force of Swedish MNEs worked in industrialized countries (ITPS 2004). The co-existence of both market-seeking and cost-reducing forces makes theoretical predictions about the effect of outward FDI on real wages ambiguous. Moreover, even when considering exclusively cost-reducing FDI, the theoretical prediction about the effect on parent employment is ambiguous. The effect depends on whether the cost reduction allows the MNE to expand its market share, and whether the parent retains activities at home that are complementary to foreign operations.

To what extent FDI may lead to reduced labor demand at home and downward pressure on home country wages is therefore inherently an empirical issue. We use data on German and Swedish MNEs at the parent and affiliate level to assess the FDI effects. We ask: (i) What factors determine where MNEs choose to operate their foreign affiliates? (ii) How is the firm's employment in different locations affected by wages in those locations?

Our German data combine information on domestic firms' balance sheets ( $U n$ ternehmensbilanzstatistik, USTAN) with information on German firms' foreign affiliate holdings (Direktinvestitionenstatistik, DIREK). Both sets of data are collected by Deutsche Bundesbank Frankfurt and matched in this paper for the first time. The German data on outward FDI cover the foreign affiliates of German MNEs (above a certain size threshold and with a ten-percent ownership share). We restrict our attention to majority-owned affiliates of German MNEs to make the data comparable across countries. The Swedish data (collected by the Research Institute of Industrial Economics IUI Stockholm) cover around 75 percent of all Swedish manufacturing companies above a certain size threshold with at least one majority-owned foreign affiliate in manufacturing. To construct comparable data for the two countries, we choose the year 2000 for Germany, the first year for which we have a full match of domestic parents and foreign affiliates, and the year 1998 for Sweden, the last currently available year of Swedish MNE data.

We run regressions of location choice with a large set of parent-level controls and location-specific variables. We also estimate multi-location translog cost functions from which we can infer the degree of substitutability between parent and affiliate employment. Our results show that German MNEs are attracted to host countries 
with relatively abundant supplies of skilled labor. This confirms recent findings for a sample of German MNEs with affiliates in Central and Eastern Europe (CEE) (Marin 2004). However, we find no such evidence for Swedish MNEs, suggesting that this tendency may indeed be particular to Germany.

Multi-location cost function estimates show that affiliate employment tends to substitute for employment at the parent firm both at German and Swedish MNEs. At the margin, this substitutability between parent and affiliate employment is most pronounced for affiliates in other Western European countries. However, we also find substitutability between parent employment and affiliate employment in Central and Eastern Europe $(C E E)$. Because of the larger wage differential between Germany and Sweden on the one hand and $C E E$ on the other hand, than between different Western European countries, this may be the economically more important effect. An evaluation of our multi-location cost function estimates at the sample mean shows that a one percent larger wage gap between Germany and locations in CEE may destroy around 900 jobs in German parents and create around 5,0000 in affiliates located in CEE. A similar evaluation for Sweden shows that a one percent larger wage gap between Sweden and CEE may destroy 140 jobs in Swedish parents and create around 260 jobs in affiliates located in $C E E$.

The remainder of this paper is organized as follows. We document overall employment trends for MNEs operating in Sweden and Germany in section 2 and discuss the related literature. Section 3 presents our econometric frameworks, and section 4 describes the data on MNEs used. We present the empirical analysis of location choice in section 5 and the analysis of employment responses to wages across different locations in section 6 . Section 7 concludes.

\section{German and Swedish FDI and Related Litera- ture}

In 2001, German MNEs employed about 2.5 million workers abroad, and Swedish MNEs around one million workers (see figures 1 and 2). Whereas employment at German parents roughly matches in size the employment at foreign affiliates, employment at Swedish parents is only about half of their employment at foreign affiliates.

Affiliate employment of German and Swedish MNEs roughly doubled over the course of the 1990s. In Germany, employment at the parent firms increased over this period as well. At face value, these facts do not provide evidence in support of the widely held opinion that German MNEs have shifted employment to foreign locations. In contrast, Swedish parent employment fell during the same period-lending more support to the notion that MNEs contribute to a relocation of jobs abroad. Our analysis will show, however, that when we study employment patterns at the level of firms, employment responses to wage differentials between home and host countries are very similar for Swedish and German MNEs. 


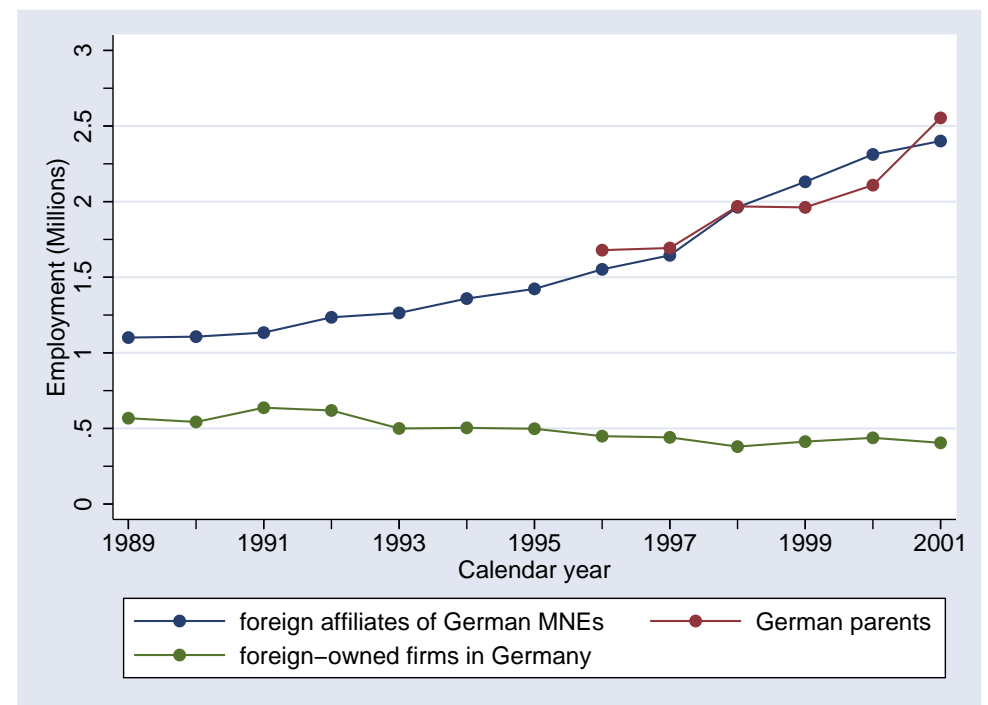

Source: Own calculations (foreign employment at majority-owned affiliates only). Data: DIREK and USTAN Deutsche Bundesbank, all sectors.

\section{Figure 1: Employment at German MNEs}

Recently, outward FDI from Germany and Sweden to CEE has surged. Both countries are close to recent accession countries to the European Union (EU); Germany to the Czech Republic, Poland and Hungary; Sweden to the Baltic states and Poland. Firms in both Germany and Sweden may realize potentially large labor cost reductions by relocating activities to $C E E$. The focus of this paper on manufacturing activities notwithstanding, a large share of recent outward FDI from both Germany and Sweden has taken place in the service sector. At both German and Swedish MNEs, roughly 40 percent of their foreign employees work in service industries (Becker, Ekholm, Jäckle and Muendler 2004, ITPS 2004).

Germany has long been an important host country of foreign MNEs, whereas Sweden received little inward FDI until the mid 1990s. Figures 1 and 2 show, however, that Germany's and Sweden's recent experiences tend to partly reverse this pattern. Employment of foreign-owned firms in Germany has fallen while employment of foreign-owned firms in Sweden has risen. Both countries have a long history as home countries of globally successful MNEs (including corporations such as Siemens, Volkswagen, Electrolux, Ericsson, and Volvo). The work force of Swedish manufacturing MNEs is, however, more international than that of German manufacturing MNEs. Table 1 shows that the foreign share of the Swedish manufacturing MNEs' work force was 59.4 percent in 1998, while the corresponding share for German manufacturing MNEs in 2000 was 39.4 percent. A likely explanation for this difference is that the larger size of the German market makes Germany a relatively more attractive production base for domestic as well as foreign firms compared to Sweden, 


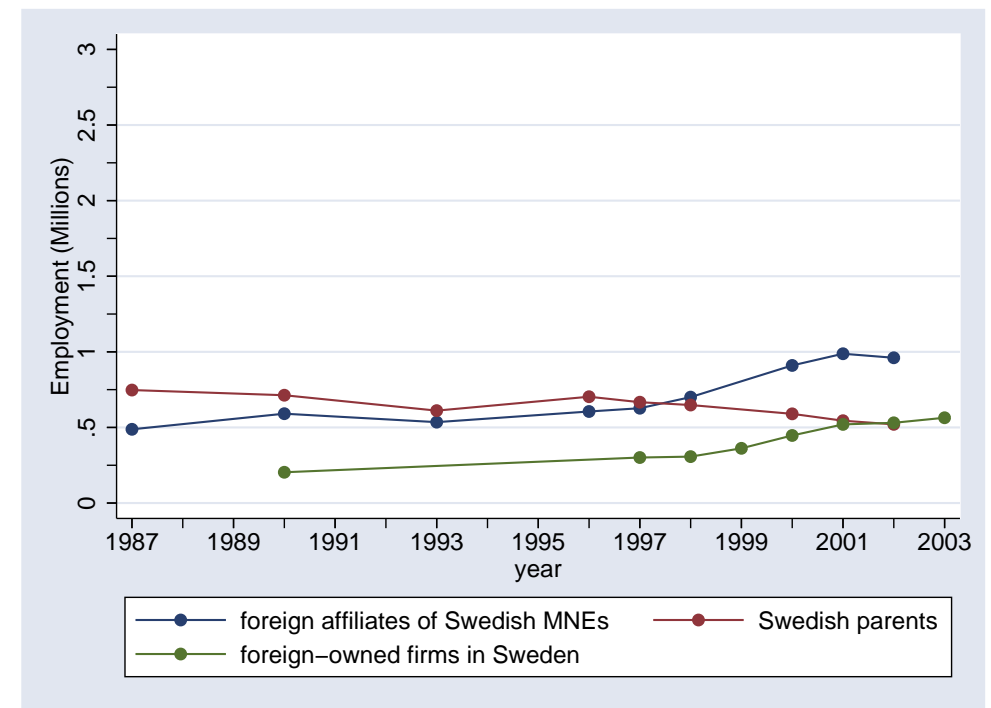

Source: Own calculations. Data: ITPS (2004), all sectors.

Figure 2: Employment at Swedish MNEs

which has a very small domestic market.

Prior research into the effect of FDI on home-country labor markets mostly focuses on the effect of locating low-skill-intensive production abroad. Feenstra and Hanson (1999) find that foreign outsourcing of U.S. firms to affiliates or unrelated firms abroad contributed substantially to the observed increase in the wage premium for skilled labor in the U.S. Slaughter (2000) studies the same issue focusing exclusively on FDI. He does not find that shifts of production activities from U.S. parents to foreign affiliates has a significant wage impact. This finding has been interpreted as evidence that the effects found by Feenstra and Hanson's (1999) is mainly related to

Table 1: Home and Foreign Employment at Manufacturing MNEs

\begin{tabular}{ccccc} 
Home $^{a}$ & WEU & OIN & CEE & DEV \\
\hline$(1)$ & $(2)$ & $(3)$ & $(4)$ & $(5)$
\end{tabular}

Germany 2000

Employment

Employment share

$1,954,379 \quad 402,885$

.125

267,077

235,009

365,826

Sweden 1998

Employment

.606

.083

.073

.113

Employment share

158,699

115,623

57,522

15,997

33,746

${ }^{a}$ Germany for German MNEs, Sweden for Swedish MNEs. 
trade at arm's length, sub-contracting or licensing. Head and Ries (2002) estimate the impact of a foreign expansion of Japanese MNEs on the skill-intensity of the work force at Japanese parents and find that foreign expansions lead to an increased skill-intensity and higher wages at the parent firm, and that this effect is stronger when firms expand into low-wage countries.

For Sweden and Germany, some studies report evidence that MNEs tend to locate relatively high-skill intensive rather than low-skill intensive activities abroad. Evidence of skill seeking among Swedish MNEs is presented by Blomström, Fors and Lipsey (1997). However, Hansson (2001) disputes their result and finds in a study similar to Slaughter (2000) that shifts of production activities within Swedish MNEs to non-OECD countries have a negative effect on the relative wage of unskilled Swedish workers. Marin (2004) presents recent evidence of skill seeking among German MNEs. She uses detailed data on German (and Austrian) MNEs and their activities in $C E E$ and finds that the foreign affiliates tend to employ workers with higher educational attainment and offer more R\&D related occupations than the German (and Austrian) parents.

For an assessment of the effects of outward FDI on the home economy it is instructive to know what factors attract FDI to foreign locations in the first place. A few studies analyze how host country factors affect the location choice of MNEs. Head and Mayer (2002) examine whether market potential is an important factor for the location choice of Japanese MNEs. Based on the same affiliate-level data as we use, Buch, Kleinert, Lipponer and Toubal (2004) study the location choice of German MNEs and argue that, on average, market access is a stronger motive than cost reduction for firms to conduct FDI. We extend their work by augmenting the affiliate-level data for Germany and Sweden with a large set of parent-level variables. We control for both relative endowments of skilled labor and labor cost differentials between the home and host country, and find that German MNEs tend to seek skill abundant foreign locations while, conditional on skill endowments, high labor costs deter FDI.

We complement the evidence on location choice with an investigation into whether parent and affiliate employment tend to substitute or complement each other. Slaughter (1995) proposes the estimation of multi-location translog cost functions in order to test whether employment at foreign affiliates tends to substitute for or be a complement to employment at domestic parent firms. Brainard and Riker (2001) and Konings and Murphy (2001) apply the translog framework to U.S. and European corporations, respectively. Brainard and Riker (2001) find that foreign affiliate employment substitutes modestly for U.S. parent employment. However, substitutability is stronger between workers employed in different low-wage locations than between parents and affiliates. Konings and Murphy (2001) find weaker substitutability between parent employment and affiliate employment in $C E E$ than between parent employment and affiliate employment in the EU-15. We follow this literature and estimate translog cost functions for German and Swedish MNEs, distinguishing be- 
tween high-income and low-income foreign locations. ${ }^{1}$

\section{Empirical Models}

An MNE's location choice and its subsequent employment decision could be viewed as a two-stage process. The MNE first chooses the location of its fixed assets - taking into account expected wage levels across regions and market prospects. Then, the MNE employs foreign workers to operate the fixed assets across locations, taking into account the prevailing wage levels in those locations and realized demand for the firm's output. We follow the existing literature closely and analyze the determinants of these decisions in two separate empirical models: A logit location choice model to capture investment in fixed assets, and an independent multi-location cost function model that considers the location choice as given.

In modeling location choice, we start from individual FDI decisions. MNEs can locate in up to $J$ countries. We follow the prior literature in that we treat location choices as independent of one another, using a multinomial choice model for the analysis. This setup rests on the implicit assumption that an MNE management board delegates the location choice to $I$ members, who individually select a location for investment out of the $J$ alternatives. While this assumption is unlikely to be strictly accurate, the setup has advantages over a simpler binomial choice model that would not allow for an analysis of host country effects on location choice. From several alternative multinomial logit models, we select the conditional logit (CL) framework. We adopt the CL framework after testing, in a more general nested logit model, whether we can reduce the number of parent-location interactions. We do not find estimates to be significantly different when reducing the number of interactions from seven to three groups of locations. A subsequent test whether the nested logit model should be adopted in lieu of the more parsimonious conditional logit model fails to reject homoskedasticity (a likelihood ratio test), suggesting that the CL model is appropriate.

\subsection{Multinomial location choice}

The benefit to a firm (or rather decision maker) $i(i=1, \ldots, I)$ of investing in country $j(j=1, \ldots, J)$ can be described with the latent variable

$$
U_{i j}^{*}=V_{i j}+\epsilon_{i j}
$$

\footnotetext{
${ }^{1}$ Related evidence is presented by Braconier and Ekholm (2000) and Marin (2004), who estimate wage elasticities without using translog cost functions. Castellani and Navaretti (2004) also study the effect of FDI on parent employment. Using propensity score matching techniques for Italian manufacturers, they find that a foreign expansion has no significant effect on employment.
} 
where $V_{i j}$ is the deterministic part and $\epsilon_{i j}$ is the stochastic part. $V_{i j}$ can, in general, be written as

$$
V_{i j}=\mathbf{x}_{i r} \beta+\mathbf{z}_{j} \gamma
$$

where $\mathbf{z}_{j}$ denotes a vector of location-specific variables and $\mathbf{x}_{i r}$ stands for a vector of firm characteristics, interacted with country group indicators $r(r=1, \ldots, R)$, that may influence the relative attractiveness of the alternatives.

The decision maker in multinomial choice models selects one out of $J$ mutually exclusive alternatives, picking the option that provides the highest benefit. The econometrician only observes the outcome. The probability of observing firm $i$ choosing alternative $j$ is

$$
\begin{aligned}
P_{i j} & =P\left(y_{i}=j\right)=P\left(U_{i j}^{*}>U_{i m}^{*} \forall m=1, \ldots, J: m \neq j\right) \\
& =P\left(\epsilon_{i m}-\epsilon_{i j} \leq V_{i j}-V_{i m} \forall m=1, \ldots, J: m \neq j\right) .
\end{aligned}
$$

Given the deterministic parts $V_{i 1}, \ldots, V_{i J}$, the probability $P_{i j}$ to observe outcome $j$ for decision maker $i$ depends on the distribution of the stochastic error term $\epsilon_{i 1}, \ldots, \epsilon_{i J}$.

The CL framework suggests an interpretation of estimation results along the following lines.

1. For country-specific variables $z_{j}$, the odds ratio (i.e. the relative probability ratio) of choosing a host country $m$ relative to not choosing the location is:

$$
\Lambda_{m \mid m^{\prime} \neq m}\left(\mathbf{x}_{i r}, \mathbf{z}_{j}\right)=\frac{P\left(y_{i}=m \mid \mathbf{x}_{i r}, \mathbf{z}_{j}\right)}{1-P\left(y_{i}=m \mid \mathbf{x}_{i r}, \mathbf{z}_{j}\right)} .
$$

Based on $\Lambda_{m \mid \neq m}$, we generate relative risk ratios (RRR) as ratios of the calculated odds ratios, where the variable of interest is increased by $\eta$ in the numerator. Using, for example, the location-specific variable $G D P_{m}, R R R$ becomes:

$$
R R R=\frac{\Lambda_{m \mid m^{\prime} \neq m}\left(G D P_{m}+\eta, \mathbf{x}_{i r}, \mathbf{z}_{j}\right)}{\Lambda_{m \mid m^{\prime} \neq m}\left(G D P_{m}, \mathbf{x}_{i r}, \mathbf{z}_{j}\right)}=\exp \left(\hat{\gamma}_{G D P} \cdot \eta\right) .
$$

For an increase of $\eta$ in $G D P_{m}$, the relative probability of investing in country $m$ versus not investing in country $m$ changes by a factor of $\exp \left(\hat{\gamma}_{G D P} \cdot \eta\right)$, holding everything else constant. For logarithmic variables one can state more explicitly that an increase in $G D P_{m}$ by one percent (i.e. $\log \left(G D P_{m} \times 1.01\right) \approx$ $\log (G D P)+.01)$ changes the relative probability of investing in country $m$ versus not choosing this location by a factor of $\exp \left(\hat{\gamma}_{G D P} \times .01\right)$.

2. The $R R R$ with respect to the (interacted) parent-specific variables, $x_{i r}$, needs to be calculated relative to a reference region $B$. Applied to domestic sectoral 
wages $w_{i C}$ (domestic wages interacted with country group indicator $C$ ), for instance, the $R R R$ becomes:

$$
R R R=\frac{\Lambda_{c \mid b}\left(w_{i}+\eta, \mathbf{x}_{i r}, \mathbf{z}_{j}\right)}{\Lambda_{c \mid b}\left(w_{i}, \mathbf{x}_{i r}, \mathbf{z}_{j}\right)}=\exp \left(\hat{\beta}_{w_{i C}} \cdot \eta\right)
$$

where $\hat{\beta}_{w_{i C}}$ is the estimated parameter of domestic sectoral wages $\left(w_{i C}\right)$ for country group $C$, and $b$ and $c$ refer to any country belonging to region $B$ and $C$, respectively. A natural interpretation of equation (6) therefore implies, that an increase in sectoral wages by $\eta$ changes the odds of choosing a location in region $C$ compared to investing in one of the countries belonging to region $B$ by the factor $\exp \left(\hat{\beta}_{w_{i C}} \cdot \eta\right) .^{2}$

\subsection{Employment responses to wages}

Given their long-term location choice across countries, we consider MNEs to be price takers in the labor markets of their domestic and foreign affiliates. A short-run translog cost function, in which installed capital is considered a quasi-fixed factor, enables us to assess how outward FDI affects home employment. We treat labor employed in a location $r$ as a distinct factor and output produced at that location as a distinct output. So, a firm $i$ produces $R$ region-specific outputs $Q_{i r}(r=1, \ldots, R)$. Considering labor as immobile across multinational locations, the parent $i$ employs $R$ different types of labor $L_{i r}(r=1, \ldots, R)$ across locations given its quasi-fixed capital stocks $K_{i r}$.

Under a common short-run translog cost function, ${ }^{3}$ firm $i$ 's cost share of labor in location $r$ is then given by

$$
\begin{aligned}
\theta_{i r}=\alpha_{r} & +\sum_{m=1}^{R} A_{r m} \ln w_{i m} \quad(r=1, \ldots, R) \\
& +\sum_{m=1}^{R} \Gamma_{r m} \ln Q_{i m}+\sum_{m=1}^{R} \Lambda_{r m} \ln K_{i m}+\epsilon_{i r}
\end{aligned}
$$

where $\theta_{i r} \equiv w_{i r} L_{i r} /\left(\sum_{m=1}^{R} w_{i m} L_{i m}\right)$ and $\epsilon_{i r}$ is a normally distributed error term with mean zero.

The signs of the $A_{r m}$ coefficients do not immediately indicate whether labor employed in one location is a substitute for or a complement to labor employed at

\footnotetext{
${ }^{2}$ Again, using logs translates the statement into: An increase of local wages by one percent (i.e. a wage increase by .01) increases the odds of investing in $C$, compared to $B$, by the factor $\exp \left(\hat{\beta}_{w_{i C}} \cdot .01\right)$.

${ }^{3}$ Burgess (1974) extends Christensen, Jorgenson and Lau's (1973) single-product translog cost function to a long-run multiproduct translog cost function. We consider capital a quasi-fixed factor in the short run and follow Brown and Christensen (1981, equation 10.21) in our specification.
} 
another location. However, we can infer Hicksian factor price elasticities $\eta_{r m}$ of labor demand responses at location $r$ to wages at location $m$ from coefficient estimates in (7) and mean cost shares. Following Anderson and Thursby (1986), we infer the wage elasticities of labor demand as

$$
\hat{\eta}_{r m}=\frac{\hat{A}_{r m}+\bar{\theta}_{r} \bar{\theta}_{m}}{\bar{\theta}_{r}}, \quad m \neq r, \quad \text { and } \quad \eta_{r r}=\frac{\hat{A}_{r r}+\bar{\theta}_{r}^{2}}{\bar{\theta}_{r}}-1,
$$

where $\bar{\theta}_{r}$ are the regional sample means of the MNEs cost shares. If labor in $r$ is a substitute for (complement to) labor in $m$, the wage elasticity $\eta_{r m}$ is positive (negative). ${ }^{4}$ That is, if an increase in wages at location $m$ leads to higher (lower) employment in location $r$, labor in $m$ is a substitute for (complement to) labor in $m$. In a translog framework, the wage elasticities $\eta_{r m}$ and $\eta_{m r}$ are not restricted to be equal (although the cost function coefficients have to be, $A_{r m}=A_{m r}$ ).

\section{Data on Domestic Parents and Foreign Affiliates}

The German data on outward FDI derive from information in Deutsche Bundesbank's (BuBa) DIREK database at the level of German parents and their foreign affiliates. All foreign affiliates fulfilling either of the following criteria are reported: (i) the parent controls at least 10 percent of equity and the balance sheet total is at least 5 million EUR; (ii) the parent controls at least 50 percent of equity and the balance sheet is at least .5 million EUR. We relegate further details on these FDI data to appendix A. To obtain comparable data to Sweden, however, we only use information on majorityowned affiliates in the present paper. We match these FDI data with information on the German parent's domestic operations from BuBa's USTAN data through string matches based on company names and addresses. USTAN is a balance-sheet data set that includes employment information. Appendix B describes the data and our string matching procedure in more detail.

The data for Sweden are part of a firm-level database on Swedish manufacturing firms with foreign production affiliates. These data derive from a comprehensive survey by the Research Institute of Industrial Economics (IUI) in Stockholm. The survey has been repeated about every fourth year since 1970. The most recent available survey covers the year 1998 (for a description of the data from this survey, see Ekholm and Hesselman 2000). The survey samples all manufacturing firms headquartered in Sweden, with at least 50 employees (world-wide) and at least one foreign affiliate with some manufacturing activity.

There are some inherent differences between the two datasets. The German dataset is much larger than the Swedish one. In the cross-section analyses we carry

\footnotetext{
${ }^{4}$ In our tests whether labor at location $r$ is a substitute $\left(\eta_{r m}>0\right)$ or complement $\left(\eta_{r m}<0\right)$ to labor at location $m$, we use the symmetric confidence interval around the estimate $\hat{\eta}_{r m}: \hat{\eta}_{r m} \pm Z(\cdot)$ as proposed by Anderson and Thursby (1986) along with confidence intervals based on a bootstrapping procedure.
} 
out in this paper, we can use information on 463 German parents while we can only use information on 94 Swedish parents. The Swedish dataset, on the other hand, contains some information which is unavailable for the German firms. In the Swedish dataset, total labor costs and employment are reported by the firms at both parent and affiliate level. Information about labor costs per employee can thus be obtained from the dataset. For German firms, we have information about employment of parents and affiliates, but no information about wage bills. This implies that we have to use information about wages from other sources when dealing with the German firms.

\section{Location Choice}

We estimate location choice with a conditional logit (CL) model (section 3.1), using as dependent variable the presence of affiliate activity by country. We carry out the analysis for one year: 2000 in the case of Germany and 1998 in the case of Sweden. The dependent variable, the presence indicator per country, takes a value of one if there is at least one majority-owned foreign manufacturing affiliate in the country.

We use parent-specific variables $\mathbf{x}_{i r}$, interacted with location characteristics, and location-specific variables $\mathbf{z}_{j}$ as regressors. Parent-specific variables include employment, (non-financial) fixed assets per employee (capital-labor ratios), profits over equity, and the wage in the parent's home sector (for Germany) or the parent's average wage per employee (for Sweden). Following Buch et al. (2004) we also include a count of the number of countries in which an MNE operates to partly control for potential unobserved parent-level effects.

The parent-specific variables are interacted with indicators of three broad country group indicators. These regional groupings are the following: Central and Eastern European countries $(C E)$, industrialized countries $(I N)$ and developing countries $(D V)$ (see table 8 for definitions). ${ }^{5}$ We choose industrialized countries as our reference group.

Our location-specific variables are intended to capture four different aspects of the host country: its market size, its relative supply of skilled labor, its labor cost level, and costs associated with trading and investing in the country. Market size is an important determinant for the market-seeking motive behind horizontal FDI. Theoretically, the effect of relative skill supplies is ambiguous (see e.g. Carr, Markusen and Maskus 2001). Theory predicts that a large difference in relative skill endowments between the home and host country promotes vertical FDI, while a small difference

\footnotetext{
${ }^{5}$ We adopt the CL model after estimating a seven-region nested logit model (not reported) and testing whether further restrictions significantly alter estimates. We are unable to reject that parameter estimates for seven regions differ significantly from those for three more aggregate regions ( $p$-value of .16), and are unable to reject that nesting the remaining three foreign regions (IN, $C E$ and $D V)$ into industrialized $(I N)$ and non-industrialized countries $(C E$ and $D V)$ changes parameter estimates.
} 
in skill endowments favors horizontal FDI. Moreover, the effects of skill endowments depend on the size of the market in the host country, since vertical FDI is most attractive when the host country has a large market at the same time as it is relatively abundant in unskilled labor (has cheap labor). Horizontal FDI, on the other hand, is most attractive when the home and host countries are similar both in terms of relative skill endowments and market size. These insights call for the inclusion of interaction terms between skill endowments and market size in a regression.

Relative labor and other factor costs may interact with location choice through an additional channel. One reason for cost differentials of factor inputs is that agglomeration forces may push up the price of immobile factors in agglomerated regions. This may create incentive for vertical FDI to low-cost locations unrelated to the relative endowments of unskilled labor in the host country (Ekholm and Forslid 2001). However, it may equally well be the case that MNEs are attracted by the location advantages that give rise to agglomeration in the first place.

According to theory, the effect of trade costs is ambiguous as well. High trade costs promote horizontal FDI since they make exports from the home country costly, while low trade costs promote vertical FDI since they make exports from the host country back to the home country inexpensive.

We proxy market size with a country's GDP, and trade and investment costs with geographical distance between the capital cities of the host and home countries. ${ }^{6}$ We use a country's share of population with completed higher education to measure relative skill endowments (taken from Barro and Lee (2001) data). The level of labor costs is approximated by the wage cost for skilled blue-collar workers. ${ }^{7}$ The choice of this particular type of labor has been motivated by the desire to find a group that might be considered reasonably homogenous and one that is likely to be important for all firms in the sample.

GDP per capita is included as an additional location-specific variable. This variable may partly capture the host country's relative abundance of physical and human capital, partly its level of technology and infrastructure, and partly income effects on consumer demand. Because of the so-called Balassa-Samuelson effect, it may also capture the host country's relative cost level and thereby be an alternative proxy for the wage level. Furthermore, GDP per capita correlates with the quality of economic and political institutions - such as property rights protection, checks on corruption and political stability. The measures of GDP and GDP per capita for are obtained from the IMF's International Financial Statistics series.

\footnotetext{
${ }^{6}$ Geographical distance is measured as the greater circle distance from Berlin and Stockholm, respectively.

${ }^{7}$ This measure has been obtained by using information on occupational wages from the Occupational Wages around the World (OWW) database (Freeman and Oostendorp 2001). See appendix C for a more detailed description of the calculations.
} 


\subsection{Location of Foreign Affiliates of German MNEs}

Table 2 presents conditional logit estimates for Germany. Investments made by the same MNE in different countries should probably not be treated as mutually independent decisions. We therefore control for potential correlations in the error terms by allowing for clustering over parent observations. ${ }^{8}$ In table 2 we have defined skillscarce (skill-abundant) countries as countries with a lower (higher) share of high school attainment than Germany (the share of higher school attainment in Germany is 17.5 percent). To increase the number of observations, we remove median foreign wages from specifications (2) and (4).

To assess the effect of relative skill endowments, we interact endowments with an indicator of whether the country is skill abundant or skill scarce compared to Germany. As discussed previously, theory predicts that differences in relative skill endowments promote vertical FDI, while similarity in relative skill endowments promotes horizontal FDI. If FDI were mainly vertical, we would expect a negative effect of skill endowments for both groups. If it were mainly horizontal, we would expect a positive effect of skill endowments for the skill scarce group and a negative effect of skill endowments for the skill abundant group. Since theory suggests that the effect varies depending on the size of the country, we also augment the specifications with further interactions between relative skill endowments and GDP for the two groups of skill scarce and skill abundant countries.

Host-country regressors are highly significant across specifications, the only exception being GDP per capita in some specifications. In particular, GDP levels and geographical distance serve as strong predictors of FDI (at the one-percent confidence level), reflecting the importance of standard gravity variables for explaining the pattern of FDI (Brainard 1997, Ekholm 1998, Shatz 2003, Venables and Shatz 2000). Larger GDP (market size) attracts FDI, while geographical distance deters FDI. In specification (1), for example, a one percent increase in a country's GDP, ceteris paribus, raises the relative probability of choosing it as a location versus not investing in this country by about half a percent in a skill scarce country and about .8

\footnotetext{
${ }^{8}$ We have also used specifications including region-specific constants. However, the inclusion of these constants did not alter the results in any important way, which is why we do not report them in the paper.
} 
Table 2: Conditional Logit Estimates of German FDI Presence in 2000

\begin{tabular}{lcccc} 
& $(1)$ & $(2)$ & $(3)$ & $(4)$ \\
\hline ln GDP & .971 & .844 & .950 & .817 \\
ln Distance & $(.085)^{* * *}$ & $(.060)^{* * *}$ & $(.086)^{* * *}$ & $(.059)^{* * *}$ \\
& -.619 & -.527 & -.577 & -.463 \\
ln Skills, scarce loc. & $(.054)^{* * *}$ & $(.045)^{* * *}$ & $(.057)^{* * *}$ & $(.046)^{* * *}$ \\
& .929 & .522 & .875 & .479 \\
ln Skills, abund. loc. & $(.191)^{* * *}$ & $(.146)^{* * *}$ & $(.193)^{* * *}$ & $(.145)^{* * *}$ \\
& .212 & .082 & .205 & .077 \\
ln Median Wage & $(.084)^{* *}$ & $(.054)$ & $(.084)^{* *}$ & $(.053)$ \\
& -.283 & & -.287 & \\
ln GDP $\times$ ln Skills, scarce & $(.115)^{* *}$ & & $(.117)^{* *}$ & \\
& -.032 & -.018 & -.030 & -.016 \\
ln GDP $\times$ ln Skills, abund. & $(.007)^{* * *}$ & $(.005)^{* * *}$ & $(.007)^{* * *}$ & $(.005)^{* * *}$ \\
& -.007 & -.003 & -.007 & -.003 \\
ln GDP per capita & $(.003)^{* *}$ & $(.002)$ & $(.003)^{* *}$ & $(.002)$ \\
& .060 & -.101 & .066 & -.128 \\
& $(.106)$ & $(.050)^{* *}$ & $(.105)$ & $(.052)^{* *}$
\end{tabular}

Parent interactions with Central and Eastern European (CE) countries

$\begin{array}{lcccc}\text { ln Location count } & -.332 & -.352 & -.259 & -.313 \\ & (.105)^{* * *} & (.101)^{* * *} & (.129)^{* *} & (.124)^{* *} \\ \ln \text { Employment } & .138 & .159 & -.006 & .042 \\ & (.031)^{* * *} & (.027)^{* * *} & (.074) & (.071) \\ \ln \text { Capital-labor ratio } & & & .028 & .058 \\ & & & (.082) & (.078) \\ \text { Profits/equity } & -.093 & -.089 & -.101 & -.095 \\ & (.056)^{*} & (.057) & (.058)^{*} & (.058)^{*} \\ \ln \text { Sector wage } & & & .104 & .060 \\ & & & (.080) & (.077)\end{array}$

Parent interactions with developing (DV) countries

$\begin{array}{lcccc}\text { In Location count } & .503 & .514 & .517 & .448 \\ & (.084)^{* * *} & (.069)^{* * *} & (.108)^{* * *} & (.089)^{* * *} \\ \text { In Employment } & -.023 & -.045 & .025 & .108 \\ & (.036) & (.027) & (.061) & (.051)^{* *} \\ \text { In Capital-labor ratio } & & & -.049 & -.016 \\ & & & (.073) & (.061) \\ \text { Profits/equity } & .013 & .003 & .016 & .011 \\ & (.022) & (.020) & (.022) & (.019) \\ \text { ln Sector wage } & & & -.033 & -.152 \\ & & & (.070) & (.057)^{* * *}\end{array}$

Sources: DIREK and USTAN. 39,429 obs. from 463 MNEs in 39 countries in col. 1 and $3(83,520$ obs. in col. 2 and 4). Standard errors in parentheses: ${ }^{*}$ significance at ten, ${ }^{* *}$ five, ${ }^{* * *}$ one percent. 
percent in a skill abundant country. ${ }^{9}$ An increase in a country's geographical distance by one percent, decreases the odds of locating in that country by about .6 percent (specification 1).

The estimated coefficient of relative skill endowments for skill scarce countries is positive and significantly different from zero at the one percent level in all specifications. The estimate for skill abundant countries is also positive, but only significance in specifications (1) and (3). This finding suggests that German MNEs are skill tracing, i.e. they seek skill-abundant locations in their selection of destinations. Skill seeking in the group of skill scarce countries is consistent with German FDI being mainly of the horizontal type. The evidence of skill seeking in the group of skill abundant countries is weaker. However, the fact that we find evidence of skill tracing in this group is interesting and may be interpreted in various ways. One possible interpretation is that German MNEs engage in a kind of inverted vertical FDI - instead of locating parts of the value added chain which are intensive in unskilled labor in low-wage countries they locate parts intensive in skilled labor in high-wage countries. Another interpretation is that the result is in fact consistent with German FDI being mainly of the horizontal type. It might be argued that formal education is a poor indicator of skill endowments in the case of Germany, since Germany has a more developed system of apprenticeship than other countries. Taking this into account, a large part of the group of countries defined as skill abundant vis-à-vis Germany might be better thought of as skill scarce.

As for the interaction terms between skill endowment and country size (measured by GDP), all estimates are negative. They are all significant for the group of skill scarce countries, but only significant in specifications (1) and (3) for the group of skill abundant countries. Higher GDP levels thus seem to be associated with a smaller impact of skill endowments. This finding is consistent with the predictions of the knowledge capital model (see Markusen 2002) and the idea that large skill scarce countries might be as attractive as small skill abundant ones. Applying the point estimates from specification (1) to numbers for Hungary and India; two examples of

${ }^{9}$ The relative risk ratio with respect to the coefficient estimate on (log) GDP must account for all interaction terms. The RRR is (see section 3 ):

$$
R R R=\exp \left[.01\left(\hat{\gamma}_{1}+\hat{\gamma}_{6} z_{m, 3}+\hat{\gamma}_{7} z_{m, 4}\right)\right]
$$

where $z_{m, 3}$ denotes the variable skill-scarce location and $z_{m, 4}$ stands for skill-abundant country, and the estimated coefficients $\gamma_{1}, \gamma_{6}$, and $\gamma_{7}$ refer to the variables $G D P_{m}$ and the interactions between skill endowment and $\log G D P_{m}$. Looking at a skill-scarce country $\left(z_{m, 4}=0\right)$ with a high school attainment rate of 15 percent $\left(z_{m, 3}=15\right)$, for instance, our results for specification (1) indicate that a one percent increase in $G D P_{m}$ increases the odds of choosing location $m$ versus not choosing it as a host country by a factor $\exp [.01 \times(.971-.032 \times 15)]=1.00492$. In other words, if the GDP in country $m$ increases by one percent, the relative probability of choosing that country versus not choosing it as a location increases by approximately .5 percent. Considering a skill-abundant country $\left(z_{m, 3}=0\right)$ with 20 percent higher school attainment $\left(z_{m, 4}=20\right)$, on the other hand, results in a factor of $\exp [.01 \times(.971-.007 \times 20)]=1.00834$. 
relatively skill-scare countries with small and large market sizes, respectively; we find that a unit increase in the skill level (i.e. an increase in the higher school attainment by one percentage point) in Hungary (India) raises the relative risk ratio of locating production there by about 15 (7) percent. The same increase in the skill level would thus have a stronger impact on the relative risk ratio of locating production there for small Hungary than for large India.

As explained above, we have also included the median wage level of skilled bluecollar workers to capture the effects of labor costs on the relative attractiveness of a location (specifications 1 and 3). Conditioning on the availability of labor skills in the country, an increase in a country's median wage of skilled blue-collar workers by one percent reduces the odds that a German MNE chooses it as a location for manufacturing activities by approximately .3 percent. Thus, while there is evidence of skill tracing conditional on wage levels, higher labor costs still deter German firms from investing in a country.

In the specifications excluding labor costs, we have many more observations at hand (specifications 2 and 4). In these specifications, the coefficient estimates for GDP per capita become negative and significant. This result may reflect the fact that GDP per capita tends to be highly correlated with wages and therefore may capture the negative effect of wages found in specifications (1) and (3). Taken together, the results for median wages of skilled blue-collar workers and GDP per capita suggest that high wage and cost levels deter German MNEs, controlling for the availability of skilled labor.

Parent-specific variables need to be interpreted relative to our reference group of industrialized countries. We exclude German sectoral wages and capital-labor ratios from specifications (1) and (2) but use a full set of parent-specific variables in specifications (3) and (4). A parent active in many locations is more likely to be present in developing countries and less likely to have invested in CEE $(C E)$ compared to the reference group. Note that the positive estimate for developing countries is likely to merely reflect the fact that this is the country group with most countries. This variable has been included only to serve as a control. Generally, the results for the parent-specific variables should be viewed as descriptive. They all relate to choice variables at the level of the firm and are therefore endogenously determined along with location choice.

The parent employment coefficient with respect to $C E E$ countries only becomes significant when German sectoral wages are excluded. A positive sign indicates that larger firms are more likely to invest in $C E E$ compared to industrialized countries. The estimated coefficient in specification (1) implies that an increase in the odds of an MNE's presence in $C E E$ (compared to its presence in industrialized countries) by a factor of $\exp (.01 \times .138)=1.00138(\approx .14$ percent $)$ goes along with a one-percent higher employment at the German parent. This correlation is consistent with the hypothesis that an MNE's presence in low-cost locations in CEE may increase its competitiveness vis-à-vis firms without such presence and therefore creates scope 
for an expansion of its activities at home. However, it should be noted that this correlation is not robust across specifications. Moreover, it would also be consistent with the hypothesis that large firms expand into $C E E$ countries more frequently than small firms.

Estimated coefficients of the profits per equity ratio are negative and significant in the CEE country group in specifications (1), (3) and (4). This suggests that parents with currently relatively low profits compared to domestic competitors are more likely to have sought cost savings by locating manufacturing production in $C E E$. The wage rate in the parent's sector in Germany, included in specifications 3 and 4, does not exhibit a conclusive correlation pattern with the choice of foreign locations. Its estimated coefficient is insignificant unless foreign wages are excluded from the regression.

\subsection{Location of Foreign Affiliates of Swedish MNEs}

Table 3 presents conditional logit estimates for Sweden. The variables included are similar to the ones in Table 2. A difference is that instead of sectoral wages in the home country, we have included the average wage in the Swedish parent. Another important difference is that parent variables now refer to the entire Swedish part of the corporation, not just the actual investing firm.

In general, fewer of the estimates based on the Swedish data set turn out significant; a reflection of the fact that the Swedish data set is much smaller. The only location-specific variables that are significant across most specifications are the standard gravity type variables; GDP and geographical distance. In specification (1), a one percent increase in a country's GDP, ceteris paribus, raises the relative probability of locating affiliate activity versus not locating affiliate activity in this country by about .4 percent in a skill scarce country and about .5 percent in a skill abundant country. ${ }^{10}$ An increase in a country's geographical distance by one percent decreases the odds of operating an affiliate there by about 1 percent.

The estimated coefficients of the host country wage level have the same negative sign as in the German case, although here they are insignificant. The estimated coefficients of relative skill abundance have the opposite sign compared to the German case, although again the estimates are insignificant. Still, the latter result implies that, unlike in the German case, there is no evidence of skill tracing by Swedish multinationals.

Most of the estimated coefficients of the parent-specific variables are insignificant as well. One apparent difference compared to the results for Germany, however, is that there is a positive estimate for the profit-equity ratio with respect to $C E E$

\footnotetext{
${ }^{10}$ Here skill abundance has been defined in relation to Sweden, whose share of "higher school attainment" is 23.1 percent. Calculating the $R R R$ for a skill abundant country yields $\exp [.01 \times$ $(.333+.008 \times 26)]=1.00543$ and for a skill scarce country $\exp [.01 \times(.333+.009 \times 11.6)]=1.00438$, using the median share of higher school attainment in the two groups of countries.
} 
Table 3: Conditional Logit Estimates of Swedish FDI Presence in 1998

\begin{tabular}{lllll} 
& $(1)$ & $(2)$ & $(3)$ & $(4)$ \\
\hline ln GDP & .333 & .343 & .338 & .481 \\
& $(.177)^{*}$ & $(.147)^{* *}$ & $(.208)$ & $(.180)^{* * *}$ \\
ln Distance & -.983 & -.973 & -1.054 & -1.089 \\
& $(.186)^{* * *}$ & $(.163)^{* * *}$ & $(.222)^{* * *}$ & $(.156)^{* * *}$ \\
ln Skills, scarce loc. & -.212 & -.166 & -.236 & -.132 \\
& $(.169)$ & $(.102)$ & $(.227)$ & $(.145)$ \\
ln Skills, abund. loc. & -.207 & -.299 & -.234 & $(.157$ \\
& $(.252)$ & $(.207)$ & $(.296)$ & \\
ln Median Wage & -.105 & & -.136 & $(.235)$ \\
ln GDP $\times$ ln Skills, scarce & $(.195)$ & & .009 & $(.005)$ \\
$\ln$ GDP $\times$ ln Skills, abund. & .008 & .007 & $(.008)$ & .007 \\
$\ln$ GDP per capita & $(.006)$ & $(.004)^{*}$ & .010 & $(.010)$ \\
& .009 & .012 & $(.011)$ & .005 \\
& $(.009)$ & $(.008)$ & -.031 & $(.141)$
\end{tabular}

Parent interactions with Central and Eastern European (CE) countries

\begin{tabular}{|c|c|c|c|c|}
\hline In Location count & $\begin{array}{l}-.113 \\
(.168)\end{array}$ & $\begin{array}{r}-.198 \\
(.168)\end{array}$ & $\begin{array}{r}-.167 \\
(.244)\end{array}$ & $\begin{array}{r}-.212 \\
(.251)\end{array}$ \\
\hline ln Employment & $\begin{array}{c}-.008 \\
(.108)\end{array}$ & $\begin{array}{l}.069 \\
(.111)\end{array}$ & $\begin{array}{l}.022 \\
(.259)\end{array}$ & $\begin{array}{l}.030 \\
(.273)\end{array}$ \\
\hline In Capital-labor ratio & & & $\begin{array}{l}.050 \\
(.258)\end{array}$ & $\begin{array}{l}.052 \\
(.266)\end{array}$ \\
\hline Profits/equity & $\begin{array}{l}1.471 \\
(.780)^{*}\end{array}$ & $\begin{array}{l}1.628 \\
(.834)^{*}\end{array}$ & $\begin{array}{l}1.865 \\
(1.154)\end{array}$ & $\begin{array}{c}1.879 \\
(1.069)^{*}\end{array}$ \\
\hline ln Parent labor cost & & & $\begin{array}{c}-.189 \\
(.302)\end{array}$ & $\begin{array}{l}.0006 \\
(.301)\end{array}$ \\
\hline \multicolumn{5}{|c|}{ Darent interactions with developing (DV) countries } \\
\hline ln Location count & $\begin{array}{c}.712 \\
(.197)^{* * *}\end{array}$ & $\begin{array}{c}.362 \\
(.180)^{* *}\end{array}$ & $\begin{array}{c}.710 \\
(.220)^{* * *}\end{array}$ & $\begin{array}{l}.277 \\
(.203)\end{array}$ \\
\hline ln Employment & $\begin{array}{l}-.189 \\
(.115)^{*}\end{array}$ & $\begin{array}{l}.031 \\
(.113)\end{array}$ & $\begin{array}{c}-.074 \\
(.162)\end{array}$ & $\begin{array}{l}.240 \\
(.176)\end{array}$ \\
\hline ln Capital-labor ratio & & & $\begin{array}{l}.150 \\
(.309)\end{array}$ & $\begin{array}{r}-.189 \\
(.295)\end{array}$ \\
\hline Profits/equity & $\begin{array}{c}-1.493 \\
(.899)^{*}\end{array}$ & $\begin{array}{l}-.929 \\
(.899)\end{array}$ & $\begin{array}{c}-1.288 \\
(1.328)\end{array}$ & $\begin{array}{l}-.928 \\
(1.186)\end{array}$ \\
\hline ln Parent labor cost & & & $\begin{array}{l}-.471 \\
(.268)^{*}\end{array}$ & $\begin{array}{r}-.117 \\
(.244)\end{array}$ \\
\hline
\end{tabular}

Source: IUI data. 7,714 obs. from 94 MNEs in 41 countries in col. 1 (13,325 obs. in col. 2; 6,554 in $3 ; 11,152$ in 4$)$. Standard errors in parentheses: ${ }^{*}$ significance at ten, ${ }^{* *}$ five, ${ }^{* * *}$ one percent. 
countries, while it is negative in the German case. It should be noted here, however, that in the Swedish case the profit-equity ratio relates to the whole corporation rather than the Swedish parent. Thus, while we found that higher profitability at the German parent was associated with a decreased probability of being located in $C E E$ compared to other regions, here we find that higher profitability at the level of the entire Swedish corporation is associated with an increased probability of being located in $C E E$ compared to other regions. However, whether higher corporate profitability is a cause or consequence of production in $C E E$ remains to be investigated.

\section{Employment and Wages Across Locations}

To assess employment effects of wages across locations, we estimate wage elasticities of labor demand across locations where the MNEs operate affiliate. The German data provide no information on firm-level employment by skill groups or occupations. We therefore only consider total employment at location $r$. We calculate the factor share in the total wage bill of MNE $i$ as $\bar{\theta}_{i, r}=\bar{w}_{r} L_{i, r} / \sum_{r=1}^{R} \bar{w}_{r} L_{i, r}$, where $\bar{w}_{r}$ is the employment-weighted regional average of the country-level wages and $L_{i, r}$ the firm's employment in region $r .{ }^{11}$ The Swedish data include the wage bills for both Swedish parents and foreign affiliates. We divide wage bills by total employment to calculate country-level wages and to infer wage shares by location.

To obtain interpretable results, we lump the host countries into four country groups: Central and Eastern Europe $(C E E)$, Developing countries $(D E V)$, Overseas Industrialized countries $(O I N)$, and Western European countries ( $W E U$ ) (see table 8 in the appendix for definitions). So, together with the home country, we consider labor demand in five distinct regions. We estimate the resulting system of $R-1=4$ independent labor share equations for the four foreign regions in iterated seemingly unrelated regressions. The iterations remove a potential sensitivity of estimates to our choice of four out of five equations, and seemingly unrelated regressions yield standard errors that account for cross-equation correlations. We assume labor to be homogenous within but not across regions. The four-equation system is

$$
\begin{aligned}
\bar{\theta}_{i, r} & =\alpha_{r}+\sum_{m=1}^{R} A_{r, m} \ln \bar{w}_{m}+\sum_{m=1}^{R} \Gamma_{r, m} \ln Q_{i, m}+\sum_{m=1}^{R} \Lambda_{r, m} \ln K_{i, m}, \\
r & =1, \ldots R-1 .
\end{aligned}
$$

The definition of cost shares implies that $\sum_{r=1}^{R} \theta_{i, r}=1$, so that the system can only be identified for $R-1$ independent equations.

\footnotetext{
${ }^{11}$ Since individual firms in our samples of 451 German and 92 Swedish parents contribute little to overall affiliate employment in a region, we consider the potential endogeneity of employment shares in our weighting procedure as negligible.
} 
Table 4: Estimates of Factor Elasticities for Germany 2000

Wage change (by 1\%) in

\begin{tabular}{lccccc} 
Employment & \multicolumn{1}{c}{ GER } & WEU & OIN & CEE & DEV \\
\cline { 2 - 6 } change (\%) in & \multicolumn{1}{c}{$(1)$} & \multicolumn{1}{c}{$(2)$} & \multicolumn{1}{c}{$(3)$} & $(4)$ & \multicolumn{1}{c}{$(5)$} \\
\hline GER & -.255 & .137 & .062 & .047 & .009 \\
& $(.113)$ & $(.116)$ & $(.152)$ & $(.139)$ & $(.126)$ \\
WEU & $(.028)^{* * *}$ & $(.025)^{* * *}$ & $(.022)^{* * *}$ & $(.010)^{* * *}$ & $(.006)$ \\
& 1.241 & -.920 & -.157 & -.106 & -.057 \\
& $(1.059)$ & $(1.376)$ & $(1.261)$ & $(1.142)$ & $(.737)$ \\
OIN & $(.185)^{* * *}$ & $(.198)^{* * *}$ & $(.109)$ & $(.092)$ & $(.037)$ \\
& 1.036 & -.292 & -.829 & -.037 & .122 \\
& $(1.735)$ & $(2.342)$ & $(3.856)$ & $(3.598)$ & $(1.662)$ \\
CEE & $(.357)^{* * *}$ & $(.193)$ & $(.848)$ & $(.760)$ & $(.182)$ \\
& 2.151 & -.531 & -.099 & -.680 & -.842 \\
& $(4.270)$ & $(5.721)$ & $(9.704)$ & $(9.676)$ & $(4.190)$ \\
DEV & $(.271)^{* * *}$ & $(.428)$ & $(2.162)$ & $(2.474)$ & $(.459)^{*}$ \\
& .973 & -.675 & .774 & -1.983 & .911 \\
& $(6.572)$ & $(8.701)$ & $(10.562)$ & $(9.875)$ & $(7.272)$ \\
& $(.667)$ & $(.408)^{*}$ & $(1.202)$ & $(1.173)^{*}$ & $(.795)$
\end{tabular}

Observations $\quad 451$

Sources: DIREK and USTAN data. Stacked Observations based on OWW wages and firm-level cost shares. Standard errors in parentheses: ${ }^{*}$ significance at ten, ${ }^{* *}$ five, ${ }^{* * *}$ one percent. Upper entries in parentheses are standard errors from Anderson and Thursby (1986) confidence interval estimates (appendix D). Lower entries in parentheses are standard errors from 1,000 bootstraps.

We approximate the MNE's value added at a location with total affiliate turnover. Potential presence in up to four foreign regions implies that there are up to 15 regional presence patterns for an MNE (permutations of the absence from none, one, two, or three regions). Rather than estimating separate equations for each location pattern, we choose to restrict the coefficients to be equal across all groups of potential patterns of foreign presence. To do so, we stack the observations by setting all variables to zero for an absent MNE and add according region indicators. The indicators take a value of one for all regions from which an MNE is absent to correct the intercept accordingly. This procedure improves efficiency, collapses the up to 15 sets of estimates into one consistently estimated four-equation system, and ultimately provides us with one single matrix of estimates for wage elasticities of regional labor demands.

Tables 9 and 10 in the appendix show the labor share estimates from the fourequation system, and table 11 presents the coefficient estimates of absence indicators for both countries. When significant, the estimates of the absence indicators reveal that absence is correlated with high regional wage bills (among the present MNEs). In neither firm sample are there any MNEs with a simultaneous presence in all four 
Table 5: Estimates of FActor Elasticities for Sweden 1998

Wage change (by 1\%) in

\begin{tabular}{lccccc}
\multirow{2}{*}{$\begin{array}{l}\text { Employment } \\
\text { change }(\%) \text { in }\end{array}$} & SWE & WEU & OIN & CEE & DEV \\
\cline { 2 - 6 } & \multicolumn{1}{c}{$(1)$} & \multicolumn{1}{c}{$(2)$} & $(3)$ & $(4)$ & \multicolumn{1}{c}{$(5)$} \\
\hline SWE & -.414 & .257 & .063 & .093 & .001 \\
& $(.235)$ & $(.190)$ & $(.202)$ & $(.153)$ & $(.165)$ \\
WEU & $(.078)^{* * *}$ & $(.063)^{* * *}$ & $(.028)^{* *}$ & $(.056)^{*}$ & $(.002)$ \\
& .648 & -.671 & .046 & -.021 & -.002 \\
& $(.483)$ & $(.516)$ & $(.387)$ & $(.416)$ & $(.112)$ \\
OIN & $(.137)^{* * *}$ & $(.194)^{* * *}$ & $(.103)$ & $(.096)$ & $(.010)$ \\
& .441 & .127 & -.663 & .094 & .001 \\
& $(1.092)$ & $(1.074)$ & $(1.029)$ & $.945)$ & $(.237)$ \\
CEE & $(.183)^{* *}$ & $(.302)$ & $(.461)$ & $(.360)$ & $(.042)$ \\
& 1.782 & -.158 & .258 & -1.938 & .056 \\
& $(3.804)$ & $(3.170)$ & $(2.598)$ & $(4.074)$ & $(.972)$ \\
DEV & $(.935)^{*}$ & $(.833)$ & $(1.089)$ & $(1.345)$ & $(.127)$ \\
& .197 & -.167 & .037 & .590 & -.658 \\
& $(9.376)$ & $(8.907)$ & $(6.819)$ & $(10.187)$ & $(7.851)$ \\
& $(.491)$ & $(.842)$ & $(1.322)$ & $(1.191)$ & $(1.810)$
\end{tabular}

Observations $\quad 92$

Source: IUI data. Stacked Observations based on observed affiliate wages and firm-level cost shares. Standard errors in parentheses: ${ }^{*}$ significance at ten, ${ }^{* *}$ five,,${ }^{* *}$ one percent. Upper entries in parentheses are standard errors from Anderson and Thursby (1986) confidence interval estimates (appendix D). Lower entries in parentheses are standard errors from 1,000 bootstraps.

foreign regions. ${ }^{12}$

Tables 4 and 5 present cross-wage elasticities of labor demand derived from the multi-location cost function estimates (tables 9 and 10). The estimates show the percentage responses of regional employment to one-percent wage increases by region.

The upper standard errors reported in tables 4 and 5 are from Anderson and Thursby (1986) confidence interval estimates (see appendix D), based on hypothesized Gaussian errors. We also obtain standard errors from 1,000 bootstraps to remove dependence on distributional assumptions and report those as the lower entries in tables 4 and 5. We judge the significance of point estimates on the basis of the bootstrapped standard errors.

Concavity of the cost function in wages requires that labor demand elasticities on the diagonal be negative. Assuringly, tables 4 and 5 do exhibit negative elasticities on the diagonal (except for one insignificant point estimate for affiliates of German

\footnotetext{
${ }^{12}$ Outside manufacturing, there is a total of 63 omnipresent MNEs in Germany in 2000 (in DIREK and USTAN).
} 
MNEs located in developing countries $(D E V)$ ). Elasticities off the diagonal can have mixed signs and provide an indication of factor substitutability (positive sign) and factor complementarity (negative sign) across locations.

Elasticities of home-country employment with respect to foreign wages (first row) and elasticities of foreign employment with respect to home country wages (first column) are all positive in (tables 4 and 5). In both the German and Swedish sample, the estimated cross-wage elasticities are significant at least at the ten percent level for all regions except developing countries. In the larger German sample, several estimates are significant at the one-percent level. The positive and significant estimates suggest that jobs at foreign locations substitute for employment at the German and Swedish parents. Parent employment seems to be the most sensitive to wages in Western European host countries. At the sample mean, a one percent lower wage in Western European host countries is associated with .11 percent smaller employment in German parents. Similarly, a one percent lower wage in Western European countries is associated with .23 percent smaller employment in Swedish parents.

The finding that affiliate employment in other high-income countries is the strongest substitute for parent employment is in line with results from previous studies (e.g. Brainard and Riker 2001 and Konings and Murphy 2001). For Germany and Sweden, home employment is most sensitive to wages in Western European host countries. Whereas Konings and Murphy (2001) find no or only weak evidence of substitution between parent employment in EU-15 and affiliate employment in CEE, our results do suggest such a relationship. German MNEs that face a one percent higher wage at home are estimated to increase their employment in $C E E$ by 2.2 percent. Swedish MNEs that face a one percent higher wage at home are estimated to increase their employment in $C E E$ with 1.8 percent. A one percent wage reduction in host countries in $C E E$ reduce German parent employment by about .05 percent and Swedish parent employment by about .09 percent.

For both German and Swedish MNEs, a one-percent larger wage gap between $C E E$ and the home country results in significantly stronger employment effects in $C E E$ than in the home country. The different magnitudes reflect labor productivity differences between the home country and $C E E$ as captured by the estimated multilocation cost function. A substitution of parent jobs for affiliate jobs in $C E E$ requires a more than proportional number of hires of lower-productivity workers in CEE. Moreover, a one-percent change in German or Swedish wages implies a considerably larger absolute change in wage levels and can therefore have a stronger effect on affiliate employment in $C E E$ than a one-percent wage change in $C E E$ has on parent employment.

Most of the cross-wage elasticities between different foreign locations are insignificant. For German MNEs, there are a few instances of negative cross-wage elasticities significant at the 10 percent level: the elasticities of affiliate employment in developing countries with respect to wages in Western Europe and $C E E$, and the elasticity of affiliate employment in $C E E$ with respect to wages in developing countries. These 
Table 6: Employment Effects of a One-Percent Increase in the Wage Differential Relative to Foreign Locations

\begin{tabular}{lrrrr} 
& WEU & OIN & CEE & DEV \\
\cline { 2 - 5 } & $(1)$ & $(2)$ & $(3)$ & $(4)$ \\
\hline Germany (wages) & & & & \\
Home employment & -2672.8 & -1202.2 & -925.6 & -177.6 \\
Foreign employment & 4998.5 & 2767.2 & 5055.5 & 3559.1 \\
Sweden (labor costs) & & & & \\
Home employment & -657.6 & -124.8 & -140.5 & -.6 \\
Foreign employment & 1058.2 & 277.9 & 263.3 & 59.8 \\
\hline \hline
\end{tabular}

estimates could be taken as evidence of complementarity between workers employed in different host countries. Since they all involve developing countries and Europe, this suggests that the activities carried out by German MNEs in developing countries might be vertically related to the operations at foreign affiliates in Europe.

In order to relate elasticities to absolute employment responses, we calculate the implied change in employment from a one percent larger wage gap between regions. To do so, we multiply the elasticities of labor demand with the respective total sample employment figures from table $1 .{ }^{13}$ Focusing on $C E E$, we find that a one percent larger wage gap between Germany and locations in $C E E$ reduces employment in German parents by 930 jobs and increases employment in $C E E$ affiliates by 5,060 jobs. A one percent larger gap between Sweden and locations in $C E E$ reduces employment in Swedish parents by 140 jobs and increases employment in $C E E$ affiliates by 260 jobs.

\section{Conclusion}

The analysis of location choices and employment responses among German and Swedish MNEs reveals striking differences as well as similarities. For both firm samples, the strongest predictors of location choice are host country GDP and geographical distance from the home country. This result underscores the importance of standard gravity factors for the pattern of FDI. For both samples, the foreign wage level is negatively associated with the presence of foreign affiliates, controlling for the country's relative endowment of skilled labor. A noteworthy difference in location choices between German and Swedish MNEs is that German MNEs tend to be at-

\footnotetext{
${ }^{13}$ Formally, we calculate absolute employment responses to one-percent wage changes at the sample mean by multiplying the elasticities of labor demand with the respective sample average employments by region and the number of respective observations in the sample. The latter product equals total employment.
} 
tracted to countries with relatively abundant supplies of skilled labor, while there is no evidence of such skill tracing for Swedish MNEs. In this sense, our results lend some support to recent findings that German firms locate relatively skill-intensive activities abroad (Marin 2004). However, our German data lack explicit information on the skill composition of labor forces and do not permit a more detailed analysis.

Given their respective location choices, German and Swedish firms exhibit similar responses of labor demands to international wage differentials. For both home countries, we find only positive estimates of the cross-wage elasticities. This implies that jobs at parent firms and jobs at foreign affiliates tend to substitute for one another. For both sets of firms, we find that parent employment is most responsive to wages in other Western European countries. However, our results also indicate significant substitutability between parent workers and affiliate workers in Central and Eastern Europe. While parent employment is less responsive to a one-percent wage change in $C E E$ than to a one-percent wage change in Western Europe, the employment effects of the wage differentials between the home countries and $C E E$ may be economically the more important effects. The wage differential between the home countries Germany and Sweden on the one hand and $C E E$ on the other hand is considerably larger than the wage differential between these countries and other Western European countries.

The estimated labor demand elasticities apply to marginal wage changes across locations in which MNEs own manufacturing affiliates. An evaluation as to how large wage changes would affect employment in different locations is beyond the scope of this paper. Such an assessment would require the treatment of endogenous location choices in estimating the employment responses of MNEs. 


\section{Appendix}

\section{A The BuBa FDI data}

We use FDI data for the years 1989 through 2001 at the firm level from BuBa's DIREK (Direktinvestitionenstatistik) database. Panels of both individual parents and affiliates are identifiable during the sub period 1996 through 2001. Exchange rate information at the balance sheet closing dates is available. We derive two data sets from the original data.

1. Raw data. The raw FDI data are available as a three-dimensional panel, where observations can be thought of as indexed by parent $i$, foreign affiliate $u$, and year $t$. Every observation in the raw data corresponds to a single "K3 questionnaire" (K3 meaning reported outward FDI from Germany).

2. Parent-host-country aggregates. Using the raw FDI data, we derive a three-dimensional panel indexed by parent, host country of affiliate and year. Whenever a parent carries out multiple investments in a particular country, we aggregate these investments into one observation. We interpret investments of the same parent firm in different countries as independent location decisions conducted by independently operating parts of the firm (but restrict standard errors to by clustered by parent company). Every observation in this data set can be thought of as indexed by $i, j, t$ where $i$ denotes the German parent, $j$ denotes the host country, and $t$ the year.

Currency conversion and deflation. We convert all economic data of foreign affiliates into euro (EUR) and deflate them. In BuBa's original DIREK data, all information on foreign affiliates is reported in German currency, using the exchange rate at the closing date of the foreign affiliate's balance sheet. We apply the following deflation and currency conversion method to all financial variables. (i) We use the market exchange rate on the end-of-month day closest to an affiliate's balance sheet closing date to convert the DEM figures into local currency for every affiliate. This reverses the conversion applied to the questionnaires at the date of reporting. (ii) A deflation factor for every country deflates the foreign-currency financial figures to the December-1998 real value in local currency. (iii) For each country, the average of all end-of-month exchange rates vis-à-vis the DEM between January 1996 and December 2001 is used as a proxy for the purchasing power parity of foreign consumption baskets relative to the DEM. All deflated local-currency figures are converted back to DEM using this purchasing-power proxy. The resulting deutschmark (DEM) figures are then converted into euro figures at the rate 1.95583 (the conversion rate at inception of the euro in 1999).

We use the foreign countries' CPIs (Consumer Price Indices from the IMF's International Financial Statistics) to deflate the figures. Whenever a country's CPI is not available from IFS but the main currency used in that country is issued in some other country, we use the CPI of the currency-issuing country. The CPI deflation factors for all countries are rebased to unity at year-end 1998. 


\section{B String matches and the BuBa USTAN data}

We string-match companies in the BuBa USTAN (Unternehmensbilanzstatistik) data set by name to companies in the Buba FDI data set in order to obtain information on the domestic operations of German MNEs. Every firm in Germany who draws a bill of exchange in a given year is required by law to report its balance sheet to $\mathrm{BuBa}$, who collects this information in its USTAN database when the bill of exchange is rediscounted. The database is considered the most comprehensive source of balance sheet data for companies outside the financial sector in Germany, and includes companies from the financial sector. The draft of bills of exchange remains a common form of payment in Germany. However, increases in BuBa's value threshold for reporting resulted in several drops of the sample and a marked decrease in the year 2001. For the year 2000, on which we base the current paper, we successfully string match a total of 1,731 USTAN firms to FDI firms. However, only 108 of those firms provide consolidated balance sheet information.

We extract USTAN information on the balance sheet total, equity (including retained profits), profits, (non-financial) fixed assets, liabilities, the number of employees, and turnover. We use the German CPI (from the IMF's International Financial Statistics) to deflate the DEM (EUR) financial figures in the USTAN data set. The CPI deflation factor is rebased to unity at year-end 1998. Deflation to year-end 1998 values makes financial figures comparable to the purchasing-power-parity inspired conversion method for our foreign financial figures. The end of 1998 is the mid point of our 1996-2001 data. In addition, the introduction of the euro in early 1999 makes December 1998 a natural reference date.

For robustness checks, we are interested in German MNEs who have only foreign but no domestic affiliates ('stand-alone' parents). For this purpose, we string-match companies in the BuBa FDI data set by name and location to companies in the firm register of the association of German credit agencies Verband der Vereine Creditreform, as available in its database MARKUS. We use the information on ownership shares from MARKUS to infer whether and how domestic firms form part of corporate trees to which BuBa Outward FDI firms belong. If no domestic affiliate is found for a BuBa Outward FDI firm, we label the FDI firm a 'stand-alone' parent.

\section{Occupational Wages}

We use wage data from the Occupational Wages around the World (OWW) database (Freeman and Oostendorp 2001). The data contain wages for 161 occupations in over 150 countries from 1983 to 1999 (the OWW data in turn are based on the ILO October Inquiry database). The OWW wages refer to average monthly wage rates for male workers. We use the 1999 data, multiply the monthly wages by twelve to approximate annual earnings for our annualized translog estimation, and aggregate the 161 occupations into five broad occupation categories comparable to those in Abowd, Kramarz and Margolis (1999). ${ }^{14}$ The occupational categories are: $O 1$ engineers, professionals, and managers; O2 technicians and technical white-collar workers; $\mathrm{O}_{3}$ other white-collar workers; $\mathrm{O}_{4}$ skilled blue-collar

\footnotetext{
${ }^{14}$ We follow Freeman and Oostendorp's (2001) recommendation and use their base calibration with lexicographic weighting for the aggregate wages.
} 
workers; and $O 5$ unskilled blue-collar workers. The skill intensity of these occupations falls with progressing number labels.

\section{Confidence interval estimator for wage elasticities of la- bor demand}

Given translog coefficient estimates $\hat{A}_{r m}$, from (9) the wage elasticity estimators for labor demand are

$$
\hat{\eta}_{r m}=\frac{\hat{A}_{r m}+\bar{\theta}_{r} \bar{\theta}_{m}}{\bar{\theta}_{r}}, \quad m \neq r, \quad \text { and } \quad \eta_{r r}=\frac{\hat{A}_{r r}+\bar{\theta}_{r}^{2}}{\bar{\theta}_{r}}-1,
$$

with confidence intervals in the normal-distribution case (Anderson and Thursby 1986)

$$
\hat{\eta}_{r m} \pm z_{0}\left[\hat{\eta}_{r m}^{2} \sigma_{\theta_{r}}^{2} / I-2 \zeta_{r m} \hat{\eta}_{r m} \sigma_{\theta_{r}}\left(\hat{\sigma}_{A, r m}^{2}+v_{r m}^{2}\right)^{\frac{1}{2}} / I^{\frac{1}{2}}+\hat{\sigma}_{A, r m}^{2}+v_{r m}^{2}\right]^{\frac{1}{2}} / \bar{\theta}_{r},
$$

where $z_{0}$ is the critical value from the standard normal distribution, $I$ the sample size, $\bar{\theta}_{r}$ and $\sigma_{\theta_{r}}$ are the sample mean and sample standard deviation of $\theta_{i r}, \hat{\sigma}_{A, r m}^{2}$ is the estimated standard error of $\hat{A}_{r m}$,

$$
\begin{aligned}
\zeta_{r m} & =\left[\rho_{\theta_{r}, \theta_{r} \theta_{m}} \sigma_{\theta_{r}} \sigma_{\theta_{r} \theta_{m}}+(I-1) \bar{\theta}_{r}\left(\sigma_{\theta_{r}}^{2}-\bar{\theta}_{r} \bar{\theta}_{m}+\overline{\theta_{r} \theta_{m}}\right)\right] / I^{2}, \\
v_{r m}^{2} & =\left[\bar{\theta}_{r}^{2} \sigma_{\theta_{m}}^{2}+\bar{\theta}_{m}^{2} \sigma_{\theta_{r}}^{2}+2 \rho_{\theta_{r}, \theta_{m}} \bar{\theta}_{r} \bar{\theta}_{m} \sigma_{\theta_{r}} \sigma_{\theta_{m}}+\left(1+\rho_{\theta_{r}, \theta_{m}}\right) \sigma_{\theta_{r}}^{2} \sigma_{\theta_{m}}^{2}\right] / I,
\end{aligned}
$$

and $\rho_{\theta_{r}, \theta_{m}} \equiv \operatorname{Cov}\left(\theta_{i r}, \theta_{i m}\right) / \sigma_{\theta_{r}} \sigma_{\theta_{m}}$ and $\rho_{\theta_{r}, \theta_{r} \theta_{m}} \equiv \operatorname{Cov}\left(\theta_{i r}, \theta_{i r} \theta_{i m}\right) / \sigma_{\theta_{r}} \sigma_{\theta_{r} \theta_{m}}$ are sample correlations. Note that $\zeta_{r m}$ is the estimated correlation between the numerator and denominator of $\hat{\eta}_{r m}$, conditional on zero correlation between $1+A_{r m} / \bar{\theta}_{r} \bar{\theta}_{m}$ (the Allen partial elasticity of substitution) and $\bar{\theta}_{r}$. 


\section{Table 7: Description of VARIABles}

Variable Description

Logit Regressions for Location Choice

$\begin{array}{ll}\text { GDP }^{a} & \text { Host country GDP (Dec/31/1998 Euros) } \\ \text { GDP per capita }^{a} & \text { Host country GDP per capita (Dec/31/1998 Euros) }\end{array}$

Distance

Geographical distance between capital cities of home (Berlin, Stockholm) and host country (greater circle distance)

Skills $^{b}$

Percentage of adults with some higher-school attainment 1999

(Barro and Lee 2001)

Location count $^{a} \quad$ Number of host countries with MNE employment per region

Employment $^{a} \quad$ Number of employees at parent firm

Capital-labor ratio $^{a, c}$ Fixed assets per employee at parent firm (Dec/31/1998 Euros)

Profit-equity ratio $^{a} \quad$ Before tax profits per equity (at parent for German MNEs; corporation-wide for Swedish MNEs)

Sector wage $^{a} \quad$ Mean gross monthly earnings in sector of German parent 2000 (two-digit NACE; data from German statistical office)

Parent labor $\operatorname{costs}^{a} \quad$ Mean reported labor cost at Swedish parent 1998

Median wage $\quad$ Median monthly wages of skilled blue collar workers abroad; based on 1999 OWW data (Freeman and Oostendorp 2001; skilled blue collar workers defined as in Abowd et al. 1999)

Translog Regressions for Wage Elasticities of Labor Demand

Wages $\quad$ Annualized region averages of OWW median wages 1999 (see above); also used for employment at German parents

Labor $\operatorname{costs}^{a}$

Turnover $^{a}$ Region averages of reported labor costs at Swedish affiliates

Fixed $\operatorname{assets}^{a}$

World-wide sales (Dec/31/1998 Euros)

Fixed assets (Dec/31/1998 Euros)

${ }^{a}$ In respective years of analysis. Germany: 2000, Sweden: 1998.

${ }^{b}$ The variable Skills, scarce location is zero for a skill-abundant host country relative to the parent country and takes the skill percentage otherwise. Similarly, the variable Skills, abundant location is zero for a skill-scarce host country relative to the parent country and takes the skill percentage otherwise.

${ }^{c}$ Dec/31/1998 1,000 Euros at German parents. 
Table 8: Country Group Definitions

\begin{tabular}{|c|c|c|}
\hline $\begin{array}{r}R \epsilon \\
\text { (four) }\end{array}$ & $\begin{array}{l}\text { ions } \\
\text { (three) }\end{array}$ & Constituting countries \\
\hline WEU & $I N$ & $\begin{array}{l}\text { Western European countries } \\
\text { (EU } 15 \text { plus Norway and Switzerland) }\end{array}$ \\
\hline OIN & $I N$ & $\begin{array}{l}\text { Overseas Industrialized countries } \\
\text { including Canada, Japan, USA, Australia, New } \\
\text { Zealand as well as Iceland and Greenland }\end{array}$ \\
\hline CEE & $C E$ & $\begin{array}{l}\text { Central and Eastern European countries } \\
\text { including accession countries and candidates } \\
\text { for EU membership }\end{array}$ \\
\hline DEV & $D V$ & $\begin{array}{l}\text { Asia-Pacific Developing countries incl. Hong Kong } \\
\text { South Korea, Singapore, Taiwan, China, Mongolia } \\
\text { and North Korea; Russia and Central } \\
\text { Asian economies; other developing countries } \\
\text { including South Asia (India/Pakistan), Africa, Latin } \\
\text { America, the Middle East; including dominions of } \\
\text { Western European countries and the United States. }\end{array}$ \\
\hline
\end{tabular}


Table 9: Translog Labor Share Estimates for Germany 2000

Labor cost shares at location ${ }^{a}$

\begin{tabular}{|c|c|c|c|c|}
\hline & \\
\hline & $\begin{array}{c}\text { WEU } \\
(1)\end{array}$ & $\begin{array}{c}\text { OIN } \\
(2)\end{array}$ & $\begin{array}{c}\text { CEE } \\
(3)\end{array}$ & $\begin{array}{c}\mathrm{DEV} \\
(4)\end{array}$ \\
\hline \multicolumn{5}{|l|}{ Wages } \\
\hline GER & $\begin{array}{c}.037 \\
(.009)^{* * *}\end{array}$ & $\begin{array}{l}.010 \\
(.007)\end{array}$ & $\begin{array}{c}.024 \\
(.006)^{* * * *}\end{array}$ & $\begin{array}{l}.001 \\
(.003)\end{array}$ \\
\hline WEU & $\begin{array}{c}-.001 \\
(.016)\end{array}$ & $\begin{array}{l}-.019 \\
(.013)\end{array}$ & $\begin{array}{l}-.011 \\
(.011)\end{array}$ & $\begin{array}{c}-.006 \\
(.005)\end{array}$ \\
\hline OIN & $\begin{array}{r}-.019 \\
(.013)\end{array}$ & $\begin{array}{l}.006 \\
(.036)\end{array}$ & $\begin{array}{c}-.003 \\
(.032)\end{array}$ & $\begin{array}{l}.006 \\
(.007)\end{array}$ \\
\hline CEE & $\begin{array}{c}-.011 \\
(.011)\end{array}$ & $\begin{array}{l}-.003 \\
(.032)\end{array}$ & $\begin{array}{l}.006 \\
(.031)\end{array}$ & $\begin{array}{c}-.016 \\
(.006)^{* * *}\end{array}$ \\
\hline DEV & $\begin{array}{r}-.006 \\
(.005)\end{array}$ & $\begin{array}{l}.006 \\
(.007)\end{array}$ & $\begin{array}{c}-.016 \\
(.006)^{* * * *}\end{array}$ & $\begin{array}{c}.015 \\
(.003)^{* * *}\end{array}$ \\
\hline \multicolumn{5}{|l|}{ Turnover } \\
\hline GER & $\begin{array}{c}-.054 \\
(.006)^{* * *}\end{array}$ & $\begin{array}{l}-.033 \\
(.004)^{* * *}\end{array}$ & $\begin{array}{l}-.010 \\
(.004)^{* * *}\end{array}$ & $\begin{array}{l}-.003 \\
(.002)^{*}\end{array}$ \\
\hline WEU & $\begin{array}{c}.040 \\
(.008)^{* * *}\end{array}$ & $\begin{array}{c}-.0001 \\
(.006)\end{array}$ & $\begin{array}{l}.005 \\
(.005)\end{array}$ & $\begin{array}{l}.0008 \\
(.002)\end{array}$ \\
\hline OIN & $\begin{array}{l}-.002 \\
(.010)\end{array}$ & $\begin{array}{c}.032 \\
(.007)^{* * *}\end{array}$ & $\begin{array}{l}.0008 \\
(.006)\end{array}$ & $\begin{array}{l}-.003 \\
(.003)\end{array}$ \\
\hline CEE & $\begin{array}{c}.017 \\
(.009)^{*}\end{array}$ & $\begin{array}{l}.012 \\
(.007)^{*}\end{array}$ & $\begin{array}{l}.002 \\
(.006)\end{array}$ & $\begin{array}{l}.002 \\
(.002)\end{array}$ \\
\hline $\mathrm{DEV}$ & $\begin{array}{c}-.0006 \\
(.008)\end{array}$ & $\begin{array}{l}-.006 \\
(.006)\end{array}$ & $\begin{array}{c}.011 \\
(.005)^{* *}\end{array}$ & $\begin{array}{c}.012 \\
(.002)^{* * *}\end{array}$ \\
\hline \multicolumn{5}{|c|}{ Fixed assets } \\
\hline GER & $\begin{array}{c}.013 \\
(.006)^{* *}\end{array}$ & $\begin{array}{c}.016 \\
(.004)^{* * *}\end{array}$ & $\begin{array}{l}-.003 \\
(.003)\end{array}$ & $\begin{array}{l}-.002 \\
(.002)\end{array}$ \\
\hline WEU & $\begin{array}{l}.011 \\
(.007)\end{array}$ & $\begin{array}{l}-.002 \\
(.005)\end{array}$ & $\begin{array}{l}-.003 \\
(.004)\end{array}$ & $\begin{array}{l}.001 \\
(.002)\end{array}$ \\
\hline OIN & $\begin{array}{l}-.007 \\
(.007)\end{array}$ & $\begin{array}{c}.014 \\
(.005)^{* * *}\end{array}$ & $\begin{array}{l}.0008 \\
(.004)\end{array}$ & $\begin{array}{c}-.0003 \\
(.002)\end{array}$ \\
\hline CEE & $\begin{array}{l}.003 \\
(.009)\end{array}$ & $\begin{array}{l}-.007 \\
(.006)\end{array}$ & $\begin{array}{l}.007 \\
(.005)\end{array}$ & $\begin{array}{l}.0009 \\
(.002)\end{array}$ \\
\hline DEV & $\begin{array}{r}-.002 \\
(.007)\end{array}$ & $\begin{array}{l}-.004 \\
(.005)\end{array}$ & $\begin{array}{c}-.006 \\
(.004)\end{array}$ & $\begin{array}{c}-.003 \\
(.002)\end{array}$ \\
\hline
\end{tabular}

Sources: DIREK and USTAN data. Stacked Observations based on OWW wages and firm-level cost shares. Standard errors in parentheses: ${ }^{*}$ significance at ten, ${ }^{* *}$ five, ${ }^{* * *}$ one percent.

${ }^{a}$ Base line location Germany (GER), 451 total observations. Regressors include firm-level indicators for absence of FDI from given region and a constant (reported in table 11). 
Table 10: Translog Labor Share Estimates for Sweden 1998

Labor cost shares at location ${ }^{a}$

\begin{tabular}{|c|c|c|c|c|}
\hline & \\
\hline & $\begin{array}{c}\text { WEU } \\
(1)\end{array}$ & $\begin{array}{c}\text { OIN } \\
(2)\end{array}$ & $\begin{array}{c}\text { CEE } \\
(3)\end{array}$ & $\begin{array}{c}\text { DEV } \\
(4)\end{array}$ \\
\hline \multicolumn{5}{|c|}{ Labor costs } \\
\hline SWE & $\begin{array}{l}.005 \\
(.014)\end{array}$ & $\begin{array}{l}-.017 \\
(.009)^{*}\end{array}$ & $\begin{array}{c}.038 \\
(.015)^{* *}\end{array}$ & $\begin{array}{l}-.001 \\
(.0008)\end{array}$ \\
\hline WEU & $\begin{array}{l}.020 \\
(.016)\end{array}$ & $\begin{array}{r}-.011 \\
(.009)\end{array}$ & $\begin{array}{l}-.013 \\
(.011)\end{array}$ & $\begin{array}{l}-.001 \\
(.0008)^{*}\end{array}$ \\
\hline OIN & $\begin{array}{l}-.011 \\
(.009)\end{array}$ & $\begin{array}{l}.022 \\
(.008)^{* * *}\end{array}$ & $\begin{array}{l}.005 \\
(.007)\end{array}$ & $\begin{array}{c}-.0002 \\
(.0004)\end{array}$ \\
\hline CEE & $\begin{array}{l}-.013 \\
(.011)\end{array}$ & $\begin{array}{l}.005 \\
(.007)\end{array}$ & $\begin{array}{l}-.032 \\
(.017)^{*}\end{array}$ & $\begin{array}{l}.002 \\
(.001)^{*}\end{array}$ \\
\hline DEV & $\begin{array}{l}-.001 \\
(.0008)^{*}\end{array}$ & $\begin{array}{c}-.0002 \\
(.0004)\end{array}$ & $\begin{array}{l}.002 \\
(.001)^{*}\end{array}$ & $\begin{array}{c}.001 \\
(.0006)^{*}\end{array}$ \\
\hline \multicolumn{5}{|c|}{ Turnover } \\
\hline SWE & $\begin{array}{l}.004 \\
(.021)\end{array}$ & $\begin{array}{l}.027 \\
(.015)^{*}\end{array}$ & $\begin{array}{r}-.001 \\
(.016)\end{array}$ & $\begin{array}{c}-.0007 \\
(.0009)\end{array}$ \\
\hline WEU & $\begin{array}{c}.069 \\
(.018)^{* * *}\end{array}$ & $\begin{array}{l}-.043 \\
(.014)^{* * *}\end{array}$ & $\begin{array}{l}.0002 \\
(.012)\end{array}$ & $\begin{array}{c}-.002 \\
(.0007)^{* * *}\end{array}$ \\
\hline OIN & $\begin{array}{l}.004 \\
(.021)\end{array}$ & $\begin{array}{c}.061 \\
(.016)^{* * *}\end{array}$ & $\begin{array}{l}-.013 \\
(.014)\end{array}$ & $\begin{array}{l}-.001 \\
(.0008)\end{array}$ \\
\hline CEE & $\begin{array}{l}.011 \\
(.025)\end{array}$ & $\begin{array}{l}.011 \\
(.019)\end{array}$ & $\begin{array}{l}.004 \\
(.017)\end{array}$ & $\begin{array}{c}-.0004 \\
(.001)\end{array}$ \\
\hline DEV & $\begin{array}{l}.027 \\
(.034)\end{array}$ & $\begin{array}{l}.054 \\
(.025)^{* *}\end{array}$ & $\begin{array}{l}.007 \\
(.023)\end{array}$ & $\begin{array}{c}.012 \\
(.001)^{* * *}\end{array}$ \\
\hline \multicolumn{5}{|c|}{ Fixed assets } \\
\hline SWE & $\begin{array}{l}-.033 \\
(.019)^{*}\end{array}$ & $\begin{array}{l}-.023 \\
(.014)\end{array}$ & $\begin{array}{l}-.021 \\
(.013)^{*}\end{array}$ & $\begin{array}{c}.001 \\
(.0007)\end{array}$ \\
\hline WEU & $\begin{array}{l}.022 \\
(.016)\end{array}$ & $\begin{array}{l}.022 \\
(.012)^{*}\end{array}$ & $\begin{array}{l}.004 \\
(.010)\end{array}$ & $\begin{array}{l}.0007 \\
(.0006)\end{array}$ \\
\hline OIN & $\begin{array}{l}-.015 \\
(.020)\end{array}$ & $\begin{array}{l}-.010 \\
(.015)\end{array}$ & $\begin{array}{l}.021 \\
(.014)\end{array}$ & $\begin{array}{r}-.0007 \\
(.0008)\end{array}$ \\
\hline CEE & $\begin{array}{l}-.019 \\
(.021)\end{array}$ & $\begin{array}{l}-.004 \\
(.016)\end{array}$ & $\begin{array}{l}.001 \\
(.014)\end{array}$ & $\begin{array}{c}-.00005 \\
(.0008)\end{array}$ \\
\hline $\mathrm{DEV}$ & $\begin{array}{l}-.086 \\
(.036)^{* *}\end{array}$ & $\begin{array}{l}-.063 \\
(.027)^{* *}\end{array}$ & $\begin{array}{l}-.013 \\
(.024)\end{array}$ & $\begin{array}{l}-.004 \\
(.001)^{* * *}\end{array}$ \\
\hline
\end{tabular}

Source: IUI data. Stacked observations based on observed affiliate wages and firm-level cost shares. Standard errors in parentheses: ${ }^{*}$ significance at ten, ${ }^{* *}$ five, ${ }^{* * *}$ one percent.

${ }^{a}$ Base line location Sweden (SWE), 92 total observations. Regressors include firm-level indicators for absence of FDI from given region and a constant (reported in table 11). 
Table 11: Absence Indicators in Translog Labor Share Estimates for GERmany 2000 And SwEden 1998

\begin{tabular}{|c|c|c|c|c|}
\hline & \multicolumn{4}{|c|}{ Labor cost shares at location } \\
\hline & $\begin{array}{c}\text { WEU } \\
(1)\end{array}$ & $\begin{array}{c}\text { OIN } \\
(2)\end{array}$ & $\begin{array}{c}\text { CEE } \\
(3)\end{array}$ & $\begin{array}{c}\text { DEV } \\
(4)\end{array}$ \\
\hline \multicolumn{5}{|l|}{ Germany } \\
\hline Indic.: No presence in $W E U$ & $\begin{array}{c}.664 \\
(.171)^{* * *}\end{array}$ & $\begin{array}{r}-.195 \\
(.148)\end{array}$ & $\begin{array}{r}-.057 \\
(.121)\end{array}$ & $\begin{array}{c}-.014 \\
(.050)\end{array}$ \\
\hline Indic.: No presence in $O I N$ & $\begin{array}{l}-.311 \\
(.170)^{*}\end{array}$ & $\begin{array}{l}.672 \\
(.369)^{*}\end{array}$ & $\begin{array}{l}.011 \\
(.321)\end{array}$ & $\begin{array}{l}.007 \\
(.073)\end{array}$ \\
\hline Indic.: No presence in $C E E$ & $\begin{array}{c}.255 \\
(.132)^{*}\end{array}$ & $\begin{array}{l}.073 \\
(.261)\end{array}$ & $\begin{array}{l}.104 \\
(.255)\end{array}$ & $\begin{array}{l}-.080 \\
(.053)\end{array}$ \\
\hline Indic.: No presence in $D E V$ & $\begin{array}{r}-.077 \\
(.097)\end{array}$ & $\begin{array}{r}-.085 \\
(.080)\end{array}$ & $\begin{array}{l}-.041 \\
(.067)\end{array}$ & $\begin{array}{c}.226 \\
(.031)^{* * *}\end{array}$ \\
\hline Constant & $\begin{array}{l}-.137 \\
(.153)\end{array}$ & $\begin{array}{l}-.210 \\
(.129)\end{array}$ & $\begin{array}{r}-.007 \\
(.112)\end{array}$ & $\begin{array}{l}-.056 \\
(.043)\end{array}$ \\
\hline Observations & \multicolumn{4}{|c|}{451} \\
\hline \multicolumn{5}{|l|}{ Sweden } \\
\hline Indic.: No presence in $W E U$ & $\begin{array}{l}1.376 \\
(.227)\end{array}$ & $\begin{array}{l}-.444 \\
(.164)\end{array}$ & $\begin{array}{l}.011 \\
(.163)\end{array}$ & $\begin{array}{c}-.033 \\
(.010)\end{array}$ \\
\hline Indic.: No presence in $O I N$ & $\begin{array}{r}-.246 \\
(.250)\end{array}$ & $\begin{array}{l}.841 \\
(.188)\end{array}$ & $\begin{array}{l}.223 \\
(.166)\end{array}$ & $\begin{array}{r}-.028 \\
(.010)\end{array}$ \\
\hline Indic.: No presence in $C E E$ & $\begin{array}{r}-.202 \\
(.273)\end{array}$ & $\begin{array}{l}.194 \\
(.206)\end{array}$ & $\begin{array}{l}-.305 \\
(.203)\end{array}$ & $\begin{array}{l}.009 \\
(.012)\end{array}$ \\
\hline Indic.: No presence in $D E V$ & $\begin{array}{r}-.801 \\
(.320)\end{array}$ & $\begin{array}{l}.002 \\
(.245)\end{array}$ & $\begin{array}{r}-.110 \\
(.213)\end{array}$ & $\begin{array}{l}.120 \\
(.012)\end{array}$ \\
\hline Constant & $\begin{array}{l}.273 \\
(.347)\end{array}$ & $\begin{array}{l}-.481 \\
(.263)\end{array}$ & $\begin{array}{l}.238 \\
(.228)\end{array}$ & $\begin{array}{l}-.056 \\
(.014)\end{array}$ \\
\hline Observations & \multicolumn{4}{|c|}{92} \\
\hline
\end{tabular}


Table 12: Summary Statistics of German and Swedish Logit Data

\begin{tabular}{|c|c|c|c|c|}
\hline & \multicolumn{2}{|c|}{ Germany } & \multicolumn{2}{|c|}{ Sweden } \\
\hline & Mean & Std. Dev. & Mean & Std. Dev. \\
\hline & $(1)$ & $(2)$ & $(3)$ & $(4)$ \\
\hline FDI presence & .026 & .158 & .034 & .182 \\
\hline $\ln$ GDP & 25.504 & 1.663 & 26.086 & 1.730 \\
\hline ln Distance & 8.217 & 1.183 & 8.153 & 1.120 \\
\hline ln Skills, scarce loc. & 5.669 & 5.689 & 10.445 & 7.843 \\
\hline ln Skills, abund. loc. & 10.438 & 13.604 & 6.128 & 12.737 \\
\hline ln Median wage (monthly) & 8.539 & 1.204 & 8.632 & 1.342 \\
\hline ln GDP $\times \ln$ Skills, scarce & 141.085 & 142.054 & 272.640 & 206.180 \\
\hline ln GDP $\times$ ln Skills, abund & 277.478 & 368.901 & 168.873 & 359.248 \\
\hline ln GDP per capita & 8.631 & 1.392 & 8.782 & 1.505 \\
\hline
\end{tabular}

Parent interactions with Central and Eastern European (CE) countries

\begin{tabular}{|c|c|c|c|c|}
\hline ln Location count & .120 & .525 & .312 & 1.065 \\
\hline ln Employment & .540 & 1.930 & .691 & 2.126 \\
\hline ln Capital-labor ratio & .358 & 1.291 & 1.079 & 3.190 \\
\hline Profits/equity & .050 & .913 & .039 & .153 \\
\hline $\ln$ Parent wage ${ }^{a}$ & .609 & 2.111 & 1.081 & 3.184 \\
\hline
\end{tabular}

Parent interactions with developing (DV) countries

\begin{tabular}{|c|c|c|c|c|}
\hline ln Location count & .842 & 1.151 & 1.352 & 1.874 \\
\hline ln Employment & 3.777 & 3.721 & 2.993 & 3.562 \\
\hline ln Capital-labor ratio & 2.505 & 2.509 & 4.677 & 5.223 \\
\hline Profits/equity & .352 & 2.394 & .167 & .283 \\
\hline ln Parent wage ${ }^{a}$ & 4.265 & 3.949 & 4.686 & 5.202 \\
\hline
\end{tabular}

Observations

39,429

7,714

Statistics and counts based on full regression specification when all variables are non-missing (column 1 in tables 2 and 3).

${ }^{a}$ Sector wage in Germany, labor cost in Sweden. 
Table 13: Summary Statistics of German and Swedish Translog Data

\begin{tabular}{|c|c|c|c|c|}
\hline & \multicolumn{2}{|c|}{ Germany } & \multicolumn{2}{|c|}{ Sweden } \\
\hline & Mean & Std. Dev. & Mean & Std. Dev. \\
\hline & $(1)$ & $(2)$ & $(3)$ & $(4)$ \\
\hline \multicolumn{5}{|l|}{ Home (Germany, Sweden) } \\
\hline Wage share, Labor cost share & .844 & .176 & .655 & .246 \\
\hline Fixed assets & 17.218 & 1.773 & 16.086 & 2.000 \\
\hline Turnover & 18.361 & 1.507 & 17.743 & 1.649 \\
\hline Wages, Labor costs & 10.220 & .000 & 10.475 & .303 \\
\hline Indic.: No presence in $S W E$ & .013 & .115 & .043 & .205 \\
\hline \multicolumn{5}{|l|}{$W E U$} \\
\hline Wage share, Labor cost share & .152 & .171 & .322 & .231 \\
\hline Fixed assets & 15.014 & 1.963 & 15.461 & 2.431 \\
\hline Turnover & 16.701 & 1.670 & 17.043 & 2.147 \\
\hline Wages, Labor costs & 9.809 & .319 & 10.503 & .305 \\
\hline Indic.: No presence in $W E U$ & .395 & .489 & .217 & .415 \\
\hline \multicolumn{5}{|l|}{$O I N$} \\
\hline Wage share, Labor cost share & .069 & .127 & .275 & .220 \\
\hline Fixed assets & 14.705 & 1.803 & 15.920 & 2.409 \\
\hline Turnover & 15.842 & 1.712 & 17.559 & 2.361 \\
\hline Wages, Labor costs & 7.998 & .129 & 10.539 & .334 \\
\hline Indic.: No presence in $O I N$ & .734 & .442 & .652 & .479 \\
\hline \multicolumn{5}{|l|}{$C E E$} \\
\hline Wage share, Labor cost share & .157 & .169 & .120 & .195 \\
\hline Fixed assets & 15.624 & 2.502 & 13.999 & 1.964 \\
\hline Turnover & 17.142 & 1.859 & 15.450 & 1.934 \\
\hline Wages, Labor costs & 9.940 & .067 & 8.796 & .417 \\
\hline Indic.: No presence in $C E E$ & .685 & .465 & .728 & .447 \\
\hline \multicolumn{5}{|l|}{$D E V$} \\
\hline Wage share, Labor cost share & .025 & .058 & .020 & .022 \\
\hline Fixed assets & 14.950 & 2.151 & 15.865 & 2.091 \\
\hline Turnover & 15.902 & 1.791 & 16.511 & 2.152 \\
\hline Wages, Labor costs & 7.560 & .816 & 8.661 & .851 \\
\hline Indic.: No presence in $D E V$ & .690 & .463 & .826 & .381 \\
\hline Observations & \multicolumn{2}{|c|}{451} & \multicolumn{2}{|c|}{92} \\
\hline
\end{tabular}

Fixed assets, turnover, and annual wages reported in natural logs.

Summary statistics refer to unstacked observations (missing data excluded). 


\section{References}

Abowd, John M., Francis Kramarz, and David N. Margolis, "High Wage Workers and High Wage Firms," Econometrica, March 1999, 67 (2), 251-333.

Anderson, Richard G. and Jerry G. Thursby, "Confidence Intervals for Elasticity Estimators in Translog Models," Review of Economics and Statistics, November 1986, $68(4), 647-56$.

Barro, Robert J. and Jong-Wha Lee, "International Data on Educational Attainment: Updates and Implications," Oxford Economic Papers, July 2001, 53 (3), 541-563.

Becker, Sascha O., Karolina Ekholm, Robert Jäckle, and Marc-Andreas Muendler, "Location Choice and Employment Decisions by German Multinationals," June 2004. University of Munich, unpublished manuscript (presented at the Western Economic Association 79th Annual Conference).

Blomström, Magnus, Gunnar Fors, and Robert E. Lipsey, "Foreign Direct Investment and Employment: Home Country Experience in the United States and Sweden," Economic Journal, November 1997, 107 (445), 1787-97.

Braconier, Henrik and Karolina Ekholm, "Swedish Multinationals and Competition from High- and Low-Wage Locations," Review of International Economics, August $2000,8(3), 448-61$.

Brainard, S. Lael, "An Empirical Assessment of the Proximity-Concentration Tradeoff between Multinational Sales and Trade," American Economic Review, September 1997, 87 (4), 520-44.

and David A. Riker, "Are US Multinationals Exporting US Jobs?," in David Greenaway and Douglas R. Nelson, eds., Globalization and labour markets, VOL 2, Cheltenham, UK and Northampton, MA: Elgar, 2001, pp. 410-26.

Brown, Randall S. and Laurits R. Christensen, "Estimates of Elasticities of Substitution in a Model of Partial Static Equilibrium: An Application to US Agriculture, 19471974," in Ernst R. Berndt and Barry C. Field, eds., Modeling and measuring natural resource substitution, Cambridge, Massachusetts: MIT Press, 1981.

Buch, Claudia M., Jörn Kleinert, Alexander Lipponer, and Farid Toubal, "Determinants and Effects of Foreign Direct Investment: Evidence from German Firm-level Data," Economic Policy, 2004. forthcoming.

Burgess, David F., "A Cost Minimization Approach to Import Demand Equations," Review of Economics and Statistics, May 1974, 56 (2), 225-34.

Carr, David L., James R. Markusen, and Keith E. Maskus, "Estimating the Knowledge-Capital Model of the Multinational Enterprise," American Economic Review, June 2001, 91 (3), 693-708. 
Castellani, Davide and Giorgio Barba Navaretti, "Investments Abroad and Performance at Home: Evidence from Italian Multinationals," CEPR Discussion Paper, 2004, 4284.

Christensen, Laurits R., Dale W. Jorgenson, and Lawrence J. Lau, "Transcendental Logarithmic Production Frontiers," Review of Economics and Statistics, February 1973, 55 (1), 28-45.

Ekholm, Karolina, "Proximity Advantages, Scale Economies, and the Location of Production," in Pontus Braunerhjelm and Karolina Ekholm, eds., Economics of Science, Technology and Innovation, number 12. In 'The geography of multinational firms.', Boston, Dordrecht and London: Kluwer Academic, 1998, pp. 59-76.

and Marie Hesselman, "The Foreign Operations of Swedish Manufacturing Firms: Evidence from a Survey of Swedish Multinationals in 1998," IUI Discussion Paper, 2000,540 .

_ and Rikard Forslid, "Trade and Location with Horizontal and Vertical Multi-region Firms," Scandinavian Journal of Economics, March 2001, 103 (1), 101-18.

Feenstra, Robert C. and Gordon H. Hanson, "The Impact of Outsourcing and HighTechnology Capital on Wages: Estimates for the United States, 1979-1990," Quarterly Journal of Economics, August 1999, 114 (3), 907-40.

Freeman, Richard B. and Remco H. Oostendorp, "The Occupational Wages around the World Data File," International Labour Review, 2001, 140 (4), 379-401.

Hansson, Pär, "Skill Upgrading and Production Transfer within Swedish Multinationals in the 1990s," FIEF Trade Union Institute for Economic Research Stockholm Working Paper, January 2001, 166.

Head, Keith and John Ries, "Offshore Production and Skill Upgrading by Japanese Manufacturing Firms," Journal of International Economics, October 2002, 58 (1), $81-105$.

and Thierry Mayer, "Market Potential and the Location of Japanese Investment in the European Union," CEPR Discussion Paper, 2002, 3455.

ITPS, Svenskägda Koncerner Med Verksamhet I Utlandet 2002. Institutet för tillväxtpolitiska studier 2004. Sveriges Officiella Statistik, 2004:003.

Konings, Jozef and Alan Murphy, "Do Multinational Enterprises Substitute Parent Jobs for Foreign Ones? Evidence from European Firm Level Panel Data," CEPR Discussion Paper, 2001, 2972.

Marin, Dalia, "A Nation of Poets and Thinkers-Less so with Eastern Enlargement? Austria and Germany," CEPR Discussion Paper, 2004, 4358.

Markusen, James R., Multinational firms and the theory of international trade, Cambridge and London: MIT Press, 2002. 
Shatz, Howard J., "Gravity, Education, and Economic Development in a Multinational Affiliate Location," Journal of International Trade and Economic Development, June 2003, $12(2), 117-50$.

Slaughter, Matthew J., "Multinational Corporations, Outsourcing, and American Wage Divergence," NBER Working Paper, 1995, 5253.

, "Production Transfer within Multinational Enterprises and American Wages," Journal of International Economics, April 2000, 50 (2), 449-72.

Venables, Anthony J. and Howard J. Shatz, "The Geography of International Investment," The World Bank Policy Research Working Paper, May 2000, 2338. 


\title{
CESifo Working Paper Series
}

\author{
(for full list see www.cesifo.de)
}

1313 Kurt Schmidheiny, Income Segregation and Local Progressive Taxation: Empirical Evidence from Switzerland, October 2004

1314 David S. Evans, Andrei Hagiu and Richard Schmalensee, A Survey of the Economic Role of Software Platforms in Computer-Based Industries, October 2004

1315 Frank Riedel and Elmar Wolfstetter, Immediate Demand Reduction in Simultaneous Ascending Bid Auctions, October 2004

1316 Patricia Crifo and Jean-Louis Rullière, Incentives and Anonymity Principle: Crowding Out Toward Users, October 2004

1317 Attila Ambrus and Rossella Argenziano, Network Markets and Consumers Coordination, October 2004

1318 Margarita Katsimi and Thomas Moutos, Monopoly, Inequality and Redistribution Via the Public Provision of Private Goods, October 2004

1319 Jens Josephson and Karl Wärneryd, Long-Run Selection and the Work Ethic, October 2004

1320 Jan K. Brueckner and Oleg Smirnov, Workings of the Melting Pot: Social Networks and the Evolution of Population Attributes, October 2004

1321 Thomas Fuchs and Ludger Wößmann, Computers and Student Learning: Bivariate and Multivariate Evidence on the Availability and Use of Computers at Home and at School, November 2004

1322 Alberto Bisin, Piero Gottardi and Adriano A. Rampini, Managerial Hedging and Portfolio Monitoring, November 2004

1323 Cecilia García-Peñalosa and Jean-François Wen, Redistribution and Occupational Choice in a Schumpeterian Growth Model, November 2004

1324 William Martin and Robert Rowthorn, Will Stability Last?, November 2004

1325 Jianpei Li and Elmar Wolfstetter, Partnership Dissolution, Complementarity, and Investment Incentives, November 2004

1326 Hans Fehr, Sabine Jokisch and Laurence J. Kotlikoff, Fertility, Mortality, and the Developed World's Demographic Transition, November 2004

1327 Adam Elbourne and Jakob de Haan, Asymmetric Monetary Transmission in EMU: The Robustness of VAR Conclusions and Cecchetti's Legal Family Theory, November 2004 
1328 Karel-Jan Alsem, Steven Brakman, Lex Hoogduin and Gerard Kuper, The Impact of Newspapers on Consumer Confidence: Does Spin Bias Exist?, November 2004

1329 Chiona Balfoussia and Mike Wickens, Macroeconomic Sources of Risk in the Term Structure, November 2004

1330 Ludger Wößmann, The Effect Heterogeneity of Central Exams: Evidence from TIMSS, TIMSS-Repeat and PISA, November 2004

1331 M. Hashem Pesaran, Estimation and Inference in Large Heterogeneous Panels with a Multifactor Error Structure, November 2004

1332 Maarten C. W. Janssen, José Luis Moraga-González and Matthijs R. Wildenbeest, A Note on Costly Sequential Search and Oligopoly Pricing, November 2004

1333 Martin Peitz and Patrick Waelbroeck, An Economist's Guide to Digital Music, November 2004

1335 Lutz Hendricks, Why Does Educational Attainment Differ Across U.S. States?, November 2004

1336 Jay Pil Choi, Antitrust Analysis of Tying Arrangements, November 2004

1337 Rafael Lalive, Jan C. van Ours and Josef Zweimueller, How Changes in Financial Incentives Affect the Duration of Unemployment, November 2004

1338 Robert Woods, Fiscal Stabilisation and EMU, November 2004

1339 Rainald Borck and Matthias Wrede, Political Economy of Commuting Subsidies, November 2004

1340 Marcel Gérard, Combining Dutch Presumptive Capital Income Tax and US Qualified Intermediaries to Set Forth a New System of International Savings Taxation, November 2004

1341 Bruno S. Frey, Simon Luechinger and Alois Stutzer, Calculating Tragedy: Assessing the Costs of Terrorism, November 2004

1342 Johannes Becker and Clemens Fuest, A Backward Looking Measure of the Effective Marginal Tax Burden on Investment, November 2004

1343 Heikki Kauppi, Erkki Koskela and Rune Stenbacka, Equilibrium Unemployment and Capital Intensity Under Product and Labor Market Imperfections, November 2004

1344 Helge Berger and Till Müller, How Should Large and Small Countries Be Represented in a Currency Union?, November 2004

1345 Bruno Jullien, Two-Sided Markets and Electronic Intermediaries, November 2004

1346 Wolfgang Eggert and Martin Kolmar, Contests with Size Effects, December 2004 
1347 Stefan Napel and Mika Widgrén, The Inter-Institutional Distribution of Power in EU Codecision, December 2004

1348 Yin-Wong Cheung and Ulf G. Erlandsson, Exchange Rates and Markov Switching Dynamics, December 2004

1349 Hartmut Egger and Peter Egger, Outsourcing and Trade in a Spatial World, December 2004

1350 Paul Belleflamme and Pierre M. Picard, Piracy and Competition, December 2004

1351 Jon Strand, Public-Good Valuation and Intrafamily Allocation, December 2004

1352 Michael Berlemann, Marcus Dittrich and Gunther Markwardt, The Value of NonBinding Announcements in Public Goods Experiments: Some Theory and Experimental Evidence, December 2004

1353 Camille Cornand and Frank Heinemann, Optimal Degree of Public Information Dissemination, December 2004

1354 Matteo Governatori and Sylvester Eijffinger, Fiscal and Monetary Interaction: The Role of Asymmetries of the Stability and Growth Pact in EMU, December 2004

1355 Fred Ramb and Alfons J. Weichenrieder, Taxes and the Financial Structure of German Inward FDI, December 2004

1356 José Luis Moraga-González and Jean-Marie Viaene, Dumping in Developing and Transition Economies, December 2004

1357 Peter Friedrich, Anita Kaltschütz and Chang Woon Nam, Significance and Determination of Fees for Municipal Finance, December 2004

1358 M. Hashem Pesaran and Paolo Zaffaroni, Model Averaging and Value-at-Risk Based Evaluation of Large Multi Asset Volatility Models for Risk Management, December 2004

1359 Fwu-Ranq Chang, Optimal Growth and Impatience: A Phase Diagram Analysis, December 2004

1360 Elise S. Brezis and François Crouzet, The Role of Higher Education Institutions: Recruitment of Elites and Economic Growth, December 2004

1361 B. Gabriela Mundaca and Jon Strand, A Risk Allocation Approach to Optimal Exchange Rate Policy, December 2004

1362 Christa Hainz, Quality of Institutions, Credit Markets and Bankruptcy, December 2004

1363 Jerome L. Stein, Optimal Debt and Equilibrium Exchange Rates in a Stochastic Environment: an Overview, December 2004 
1364 Frank Heinemann, Rosemarie Nagel and Peter Ockenfels, Measuring Strategic Uncertainty in Coordination Games, December 2004

1365 José Luis Moraga-González and Jean-Marie Viaene, Anti-Dumping, Intra-Industry Trade and Quality Reversals, December 2004

1366 Harry Grubert, Tax Credits, Source Rules, Trade and Electronic Commerce: Behavioral Margins and the Design of International Tax Systems, December 2004

1367 Hans-Werner Sinn, EU Enlargement, Migration and the New Constitution, December 2004

1368 Josef Falkinger, Noncooperative Support of Public Norm Enforcement in Large Societies, December 2004

1369 Panu Poutvaara, Public Education in an Integrated Europe: Studying to Migrate and Teaching to Stay?, December 2004

1370 András Simonovits, Designing Benefit Rules for Flexible Retirement with or without Redistribution, December 2004

1371 Antonis Adam, Macroeconomic Effects of Social Security Privatization in a Small Unionized Economy, December 2004

1372 Andrew Hughes Hallett, Post-Thatcher Fiscal Strategies in the U.K.: An Interpretation, December 2004

1373 Hendrik Hakenes and Martin Peitz, Umbrella Branding and the Provision of Quality, December 2004

1374 Sascha O. Becker, Karolina Ekholm, Robert Jäckle and Marc-Andreas Mündler, Location Choice and Employment Decisions: A Comparison of German and Swedish Multinationals, January 2005 